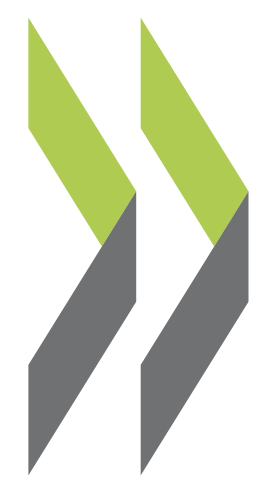

OECD Economics Department Working Papers No. 1644

\title{
The decline in labour mobility in the United States: Insights from new administrative data
}

\section{Damien Azzopardi, Fozan Fareed,} Mikkel Hermansen, Patrick Lenain, Douglas Sutherland 


\section{ECONOMICS DEPARTMENT}

THE DECLINE IN LABOUR MOBILITY IN THE UNITED STATES: INSIGHTS FROM NEW ADMINISTRATIVE DATA

\section{ECONOMICS DEPARTMENT WORKING PAPERS No. 1644}

By Damien Azzopardi, Fozan Fareed, Mikkel Hermansen, Patrick Lenain and Douglas Sutherland

OECD Working Papers should not be reported as representing the official views of the OECD or of its member countries. The opinions expressed and arguments employed are those of the author(s).

Authorised for publication by Alvaro Pereira, Director, Country Studies Branch, Economics Department.

All Economics Department Working Papers are available at www.oecd.org/eco/workingpapers.

JT03469760 
OECD Working Papers should not be reported as representing the official views of the OECD or of its member countries. The opinions expressed and arguments employed are those of the author(s).

Working Papers describe preliminary results or research in progress by the author(s) and are published to stimulate discussion on a broad range of issues on which the OECD works.

Comments on Working Papers are welcomed, and may be sent to OECD Economics Department, 2 rue André Pascal, 75775 Paris Cedex 16, France, or by e-mail to eco.contact@oecd.org.

All Economics Department Working Papers are available at www.oecd.org/eco/workingpapers

This document and any map included herein are without prejudice to the status of or sovereignty over any territory, to the delimitation of international frontiers and boundaries and to the name of any territory, city or area.

The statistical data for Israel are supplied by and under the responsibility of the relevant Israeli authorities. The use of such data by the OECD is without prejudice to the status of the Golan Heights, East Jerusalem and Israeli settlements in the West Bank under the terms of international law.

\section{() OECD (2020)}

You can copy, download or print OECD content for your own use, and you can include excerpts from OECD publications, databases and multimedia products in your own documents, presentations, blogs, websites and teaching materials, provided that suitable acknowledgment of OECD as source and copyright owner is given. Requests for commercial use and translation rights should be submitted to PubRights@oecd.org 


\section{ABSTRACT / RESUMÉ}

\section{The decline in labour mobility in the United States: Insights from new administrative data}

Job mobility is essential for a well-functioning market economy and for individual workers to boost their wages. This paper provides a re-assessment of job mobility in the United States during 2000-2018, based on a novel administrative data source covering almost all workers and job flows. First, aggregate job hire and job separation rates have declined over time, especially in the 2000s. This is mainly driven by flows into and out of nonemployment, while job-to-job hires during 2016-2018 had recovered to their peak levels prior to the global financial crisis. Examination of job mobility across different individual and firm-level characteristics shows comparatively higher job-to-job flows for youth, the less educated, non-whites and individuals working in young firms. In addition, observed job movers in these groups experience the largest earnings gain on average from job-to-job changes. Second, a spatial look at job mobility shows net job-tojob flows towards Western and Southern States. The aggregate rate of interstate job-to-job hires has been stable since 2000 and the observed job-to-job movers on average get a substantial boost to earnings by moving farther away and switching industries. Third, the paper briefly considers the influence of demographic changes on job mobility, one important driver identified in previous work. While ageing may explain around half of the downward trend in job hire and separation rates, other factors matter too.

This Working Paper relates to the 2020 OECD Economic Survey of the United States

http://www.oecd.org/economy/united-states-economic-snapshot/

JEL codes: E24, J11, J60, J61, O51

Keywords: job-to-job flows, labour mobility, geographic mobility, ageing, United States.

\section{Pourquoi la mobilité professionnelle est-elle en recul aux États-Unis ? Ce que disent de nouvelles sources de données administratives}

La mobilité professionnelle est essentielle au bon fonctionnement d'une économie de marché et à la progression du salaire de chaque travailleur. Ce document livre une réévaluation de la mobilité professionnelle aux États-Unis durant la période 2000-2018, à partir d'une nouvelle source de données administratives couvrant la quasi-totalité des actifs et des transitions professionnelles. Tout d'abord, les taux cumulés d'embauches et de cessations d'emploi ont diminué au fil du temps, en particulier au cours des années 2000. Cette diminution s'explique principalement par les transitions du non-emploi à l'emploi, tandis que les transitions d'emploi à emploi entre 2016 et 2018 ont renoué avec leurs meilleurs niveaux d'avant la crise financière mondiale. L'examen de la mobilité professionnelle au regard de différentes caractéristiques d'individus et d'entreprises fait apparaître des transitions d'emploi à emploi comparativement plus nombreuses pour les jeunes, les moins diplômés, les non-Blancs et les actifs travaillant dans des entreprises récentes. En outre, on constate que les individus qui changent d'emploi dans ces groupes sont ceux qui voient leur rémunération progresser le plus, en moyenne, du fait de ces transitions d'emploi à emploi. Ensuite, une analyse spatiale de la mobilité professionnelle révèle des flux nets d'emploi à emploi en direction des États de l'ouest et du sud du pays. Le taux cumulé de transitions d'emploi à emploi à l'intérieur d'un même État est stable depuis 2000, et l'on observe que les individus qui changent d'emploi pour un autre enregistrent, en moyenne, un gain de rémunération substantiel en allant s'installer plus loin et en changeant de secteur d'activité. Enfin, le document examine brièvement l'influence des évolutions démographiques sur la mobilité professionnelle, un déterminant important identifié dans des travaux précédents. Ainsi, si le vieillissement peut expliquer pour moitié environ cette tendance à la baisse des taux d'embauches et de cessations d'emploi, d'autres facteurs sont importants également.

Ce document de travail est lié à l'Étude économique de l'OCDE de 2020 consacrée aux États-Unis. 
4 | ECO/WKP(2020)52

http://www.oecd.org/fr/economie/etats-unis-en-un-coup-d-oeil/

Classification JEL : E24, J11, J60, J61.

Mots-clés : transitions d'emploi à emploi, mobilité professionnelle, mobilité géographique, vieillissement, États-Unis. 


\section{Table of contents}

\section{The decline in labour mobility in the United States: Insights from new administrative} data

Introduction and main findings

The Job-to-Job Flows (J2J) data

The big picture of job mobility in the United States

The spatial dimension of job mobility

The influence of demographic changes on job mobility

Concluding remarks

References

Annex A. Supplementary figures and tables

Figures

Tables

\section{Tables}

Table 1. Youth make up a substantial share of job-to-job moves 14

Table 2. Job-to-job moves across regions are much lower than mobility within regions 23

Table 3. More than half of all job-to-job hires is within States and between industries 23

Table 4. Job-to-job moves to the Northeast yields the highest earnings growth on average 27

Table 5. All age groups have positive earnings returns from interstate job-to-job moves 29

Table A.1. Employment and job-to-job distribution by sex 44

Table A.2. Employment and job-to-job distribution by education $\quad 45$

Table A.3. Employment and job-to-job distribution by race and ethnicity 45

Table A.4. Job-to-job moves within and between States and industries by sex 45

Table A.5. Job-to-job moves within and between States and industries by education 46

Table A.6. Job-to-job moves within and between States and industries by race/ethnicity 46

Table A.7. All education groups have positive earnings returns from interstate job-to-job moves 47

\section{Figures}

Figure 1. Labour market mobility has declined according to most data sources 11

Figure 2. The decline in job mobility mainly reflects fewer hires from nonemployment 12

Figure 3. Job mobility and its development varies across age groups $\quad 13$

Figure 4. Job hires from nonemployment dominate in low-skill industries $\quad 15$

Figure 5. Who has the largest job hire rates? 16

Figure 6. Who gains the most from job-to-job moves? 18

Figure 7. Which job stayers have the largest average earnings growth? 19

Figure 8. Mountain States have the highest job hire rates 20

Figure 9. Job hire rates are positively associated with population growth 20 


\section{6 | ECO/WKP(2020)52}

Figure 10. Annual interstate job-to-job moves is close to $5 \%$ of employment in many States

Figure 11. Net job-to-job moves tend to go West and South

Figure 12. The interstate job-to-job hire rate has remained stable since early 2000

Figure 13. Men and youth have the highest interstate job-to-job hire rates 25

Figure 14. The share of job-to-job moves across States increases with age 26

Figure 15. Moving farther away and switching industry is associated with earnings gain 27

Figure 16. The job-to-job earnings return varies over the cycle and across age groups 28

Figure 17. The interstate job-to-job earnings return has increased for youth and seniors 30

Figure 18. Ageing is accelerating in the United States but remains below other countries 31

Figure 19. Ageing is an important factor for the labour force participation decline 32

Figure 20. The decline in participation since 2000 is the largest across OECD countries 33

Figure 21. Employment composition has changed, notably on worker age, race and firm age $\quad 35$

Figure 22. Ageing has reduced the job hire rate substantially 36

Figure A.1. Employment distribution across industries 40

Figure A.2. Employment distribution across divisions and regions $\quad 40$

Figure A.3. Employment distribution across States $\quad 41$

Figure A.4. Job hire rates across States $\quad 41$

Figure A.5. Job mobility is lowest in the Northeast and highest in the South 42

Figure A.6. Robustness: job-to-job hire within and between States 42

Figure A.7. The interstate job-to-job earnings return has increased for low-skilled 43

Figure A.8. Changing demographics primarily affect the nonemployment hire rate 44 


\title{
The decline in labour mobility in the United States: Insights from new administrative data
}

\author{
By Damien Azzopardi, Fozan Fareed, Mikkel Hermansen, Patrick Lenain and Douglas Sutherland ${ }^{1}$
}

\section{Introduction and main findings}

1. An apparent secular decline in job mobility, interstate migration, business dynamics and productivity growth in the United States has prompted an extensive literature searching for explanations and potential remedies (e.g. Molloy et al., 2016; Abraham and Kearney, 2020). This paper uses a new dataset based on linked employer-employee data for the near universe of American workers to re-examine and take stock of the state of and trends in job mobility during 2000-2018.

2. The 2020 pandemic is provoking a massive shift in jobs across different locations, industries and age groups all over the world. Barrero et al. (2020) highlight that COVID-19 is also a reallocation shock and two out of five jobs lost during the pandemic in the U.S. may not come back. After past shocks, such as the global financial crisis, some States and industries remained depressed for a long time, while others got back on their feet and returned to growth quickly. At the time of writing, the dataset does not yet cover the pandemic shock and it is thus left for future analysis. Nonetheless, drawing lessons on job hire and job separations from the past is useful as it can provide guidance to support the recovery.

3. Job mobility is essential for a well-functioning market economy and for individual workers to boost their wages. Labour market fluidity ensures that employees can move freely from low to high productive firms, thereby increasing aggregate productivity, incomes and wellbeing prospects (Decker et al., 2017; Foster et al., 2016). Job-to-job flows tend to be a main mechanism for workers to make career progress and to increase their earnings (Hyatt et al., 2018; Haltiwanger et al., 2016). Likewise, high mobility ensures that firms experiencing a positive productivity shock can get the workers they need to expand. For these reasons, the decline in job mobility coinciding with a slowdown in productivity growth has raised much concern in the academic literature and among policymakers.

4. While population ageing can explain a sizeable part of the decline in mobility, policy factors matter as well. The role of regulatory barriers at the State level is assessed in associated work (Hermansen, 2020). Labour market regulation in the form of occupational licensing and non-competition covenants both cover more than $20 \%$ of American workers, with likely detrimental effects for mobility as well as for

\footnotetext{
1 The authors are from the OECD Economics Department at the time of writing. For valuable comments and suggestions, they would like to thank OECD colleagues Michael Koelle, Oliver Denk and Cyrille Schwellnus (OECD Economics Department); Andrea Garnero and Luca Marcolin (OECD Directorate for Employment, Labour and Social Affairs). Special thanks to Stephanie Henry for editorial assistance.
} 


\section{8 | ECONKR(2020)52}

productivity growth (Hermansen, 2019; Bambalaite et al., 2020). Empirical analysis using the same data as in this paper finds that occupational licensing is associated with lower job hire rates, particularly for interstate job-to-job moves towards States with more stringent occupational licensing regulation (Hermansen, 2019). Other types of regulation, notably land-use and housing policies, matter for mobility as well, especially as the population and jobs concentrate in cities (Azzopardi et al., 2020; Sutherland, 2020).

5. The paper starts by presenting the new Job-to-Job Flows (J2J) data from the U.S. Census Bureau. Section 3 provides an overview of job mobility across worker and firm characteristics and the developments in job hire and job separation rates during 2000-2018. It also briefly relates job mobility to the associated average earnings gains across worker characteristics. Section 4 turns to the spatial dimension of job mobility applying the information on employer geographic location to assess the trend in interstate job-tojob mobility and differences in earnings gains across groups of workers. Section 5 briefly considers the influence of demographic changes on job mobility, including a comparison of the headwind from ageing with other OECD countries.

6. The main findings of this paper are:

- Job hire and job separation rates have declined from around $13 \%$ of employment each quarter in the early 2000 s to around $11 \%$ in the late 2010 s. This decline in job mobility is mainly concentrated in the decade from 2000 to 2010 , notably during the two recessions.

- Job-to-job hires account for around half of all hires and display much more cyclical variation than hires from nonemployment. In 2016-2018, the job-to-job hire rate had recovered to its peak level prior to the global financial crisis. By contrast, hires from nonemployment have been on a steady downward trend, only interrupted by the recovery following the global financial crisis.

- Job-to-job moves are particularly important for youth as a means to move up the job ladder. Youth aged 14-24 accounts for almost a third of all job-to-job moves, but less than $15 \%$ of total employment.

- Disadvantaged groups such as youth, non-whites, less educated and employees in young firms, have the highest job hire rates and experience the largest average earnings gain in relative terms from job-to-job moves. This reflects the strong benefits of job mobility, especially in upturns, but it is also likely to be driven by less desirable conditions such as high incidences of temporary or even precarious employment.

- Job hire rates are highest in the Mountain and some Southern States and lowest in New England and some Midwest States. To some extent, this reflects differences in population growth.

- States in the West and the South have made net employment gains from interstate job-to-job moves, while many States in the Northeast and the Midwest States have experienced net losses.

- Around $16 \%$ of all the recorded job-to-job moves during 2010-2016 are between employers located in different States, with almost half being between neighbouring States.

- The interstate job-to-job hire rate has remained relatively stable just below $1 \%$ of total employment per quarter since 2000. Men and youth have the highest interstate job-to-job hire rates, while variation is much lower across education and race/ethnicity groups.

- Workers moving longer distances and switching industries tend to benefit from a sizeable earnings boost. This is highest for youth, but all age groups on average experience an important earnings increase, varying only modestly across age groups above 25 .

- The share of seniors (aged 55 and above) in total employment has risen from less than $13 \%$ to $23 \%$ from 2000 to 2018 . A shift-share calculation suggests that the job hire rate would have been 1.2 percentage points higher in 2018 if the age group composition had remained the same as in 2000. 


\section{The Job-to-Job Flows (J2J) data}

7. This section provides an overview of the main dataset and the definitions of key concepts used throughout the paper. We rely on the Job-to-Job Flows (J2J) data compiled and made available by the U.S Census Bureau. ${ }^{2}$ The J2J data are constructed from a linked employer-employee database, the Longitudinal Employer Household Dynamics (LEHD) data, which is collected by State unemployment insurance programs. The coverage of private sector employment is almost complete and most public sector employees are included (the missing employment is composed of the self-employed, contract workers, federal government jobs and others not covered by State unemployment insurance). For example, the data count an employment stock of about 131 million workers and almost 15 million job hires in 2018 Q1, of which half are job-to-job hires with information on their previous job also available.

8. The J2J data are not a typical micro-level dataset with information at the individual and firm level. Instead, semi-aggregate statistics on job mobility and transitions in and out of employment are provided on a quarterly basis across States and across different individual and firm level characteristics. This has the advantage of providing a high degree of detail covering most of the population, while avoiding issues of data confidentiality as the data are publicly available. Statistics are also available on average earnings for (stable) job stayers each quarter and for job movers by the quarter before and after a job-to-job move. The J2J data version used covers 2000 Q2 to 2018 Q1. Not all States are included throughout the period; $70 \%$ of States are available from 2001 gradually increasing to $100 \%$ from 2010 . The key concepts from the $\mathrm{J} 2 \mathrm{~J}$ dataset that have been used in this paper are listed below.

\section{Main definitions}

9. The job hire (separation) rate is defined as the number of job hires (separations) within a quarter divided by the employment stock (an average of the beginning and end of period employment). Hires and separations can be split in flows between jobs and in flows into and out of nonemployment. All the mobility rates are computed for separate groups based on worker and firm characteristics to facilitate comparison, i.e. using the number of flows and corresponding employment stock. While there is a close correspondence between job-to-job hires and job-to-job separations, the measures do not mirror each other fully since hires focus on the main job by the end of the quarter whereas separations focus on the main job in the beginning of the quarter. ${ }^{3}$

- Job hire: A worker is employed in a firm by the end of the quarter (i.e. has the largest combined earnings from this employer) and did not receive earnings from the same firm in the previous quarter.

- Job separation: A worker was employed in a firm in the beginning of the quarter (i.e. has the largest combined earnings from this employer) and did not receive earnings from the same firm in the next quarter.

- Job-to-job hire: A job hire following a separation from another firm in the quarter with no or only a brief nonemployment spell, i.e. change of employer within the same quarter or with the new employer in the subsequent quarter.

- Nonemployment hire: A job hire after no main job for at least a quarter, i.e. no earnings from the same employer in both the beginning and end of a quarter (referred to as persistent nonemployment in the $\mathrm{J} 2 \mathrm{~J}$ data).

- Earnings: Average earnings for given worker and firm characteristics are compiled from the underlying microdata by summing individual earnings received during the quarter for the set of

\footnotetext{
2 The dataset is freely available at https://lehd.ces.census.gov/data/\#j2j.

${ }^{3}$ See detailed documentation https://lehd.ces.census.gov/doc/j2j_101.pdf.
} 
workers and dividing by the number of workers in the cell. Note that this is a rough earnings measure since information on hours worked or bonuses are not available.

\section{Structure of the data and level of aggregation}

The J2J data are released by semi-aggregate tabulations. This means that the number of hires and separations is reported in cells by State, industry, worker and firm characteristics (sex, age group, race/ethnicity, education, firm age and firm size). Specifically, the data are made available in two different forms:

- J2J Counts: Includes counts of individuals with a specified job history in each quarter and details about either the destination job (hires) or the origin job (separations). For example, 1356 job-tojob hires are counted for women aged 25-34 in the management industry in New York in 2017 Q2. Average earnings of USD 16511 are reported for job stayers in the same cell.

- J2J Origin-Destination: Includes counts of job-to-job changes only and provides details about both the origin and destination job, including average earnings. For example, three men aged 35-44 made a job-to-job move from the manufacturing industry in Michigan to wholesale trade in California in 2017 Q2. Their average earnings increased from USD 43714 in the quarter prior to the move to USD 44442 in the quarter after the move. Among others, this information enables aggregate assessment of the net flow of job-to-job moves by looking at the difference in the number of total job-to-job flows coming into a State and number of job-to-job flows moving out of the State in a given time period.

10. Confidentiality of the data is protected by the use of noise infusion, whereby all the released data receive a multiplicative fuzz factor (Hyatt et al., 2017). This prevents identification at the very detailed tabulations, while leaving the aggregate measures unbiased.

\section{The big picture of job mobility in the United States}

11. Labour market mobility in the United States has declined substantially since the early 1990s, according to a range of measures and data sources (Figure 1; Hyatt and Spletzer, 2013). From the firm perspective, private-sector gross job creation (employment gains from new and expanding establishments) and gross job destructions (employment losses from closing and contracting establishments) have trended down, especially during the 2000s (Panels A and B). From the worker perspective, job hire and job separation rates (all job hires and separations in per cent of total employment) based on administrative sources dropped sharply during the two most recent recessions and only partly recovered during subsequent upturns (Panels $C$ and D). Survey-based measures of job hires and job separations also indicate a decline in mobility (Panels $E$ and F). Across measures and data sources, the decline in job mobility is concentrated in the decade from 2000 to 2010 , notably during the two recessions. 
Figure 1. Labour market mobility has declined according to most data sources

Percentage of employment; annual, quarterly or monthly rates

A. Business Dynamics Statistics (BDS)
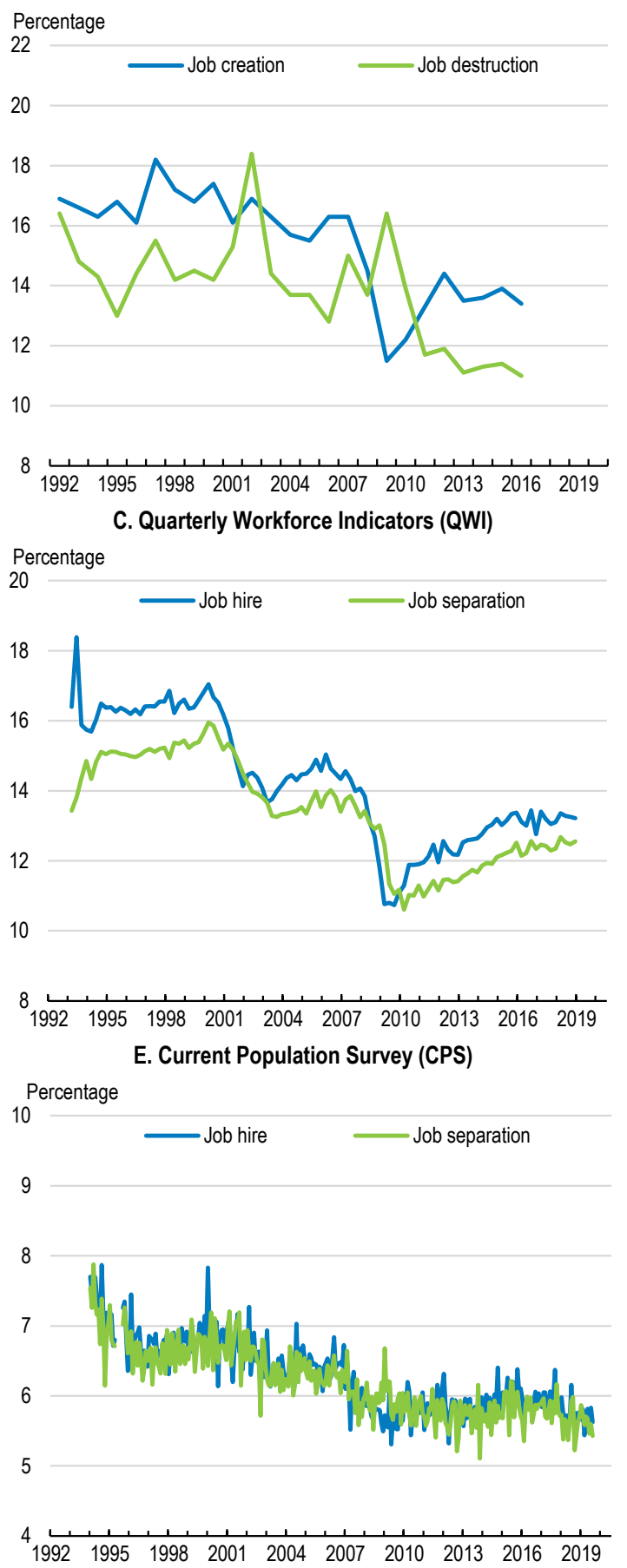

B. Business Employment Dynamics (BDM)

Percentage

$10 \longrightarrow$ Gross job gain $\quad$ Gross job loss

9

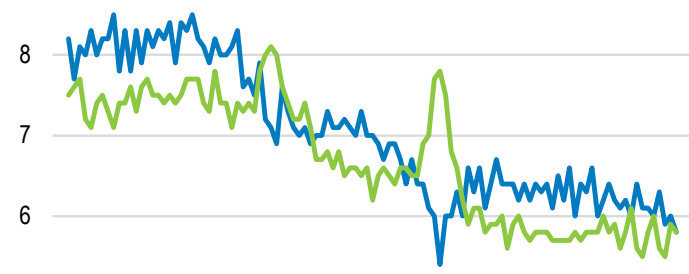

5

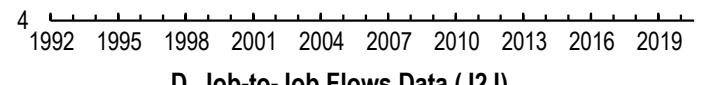

Percentage

$18 \longrightarrow$ Job hire Job separation

16

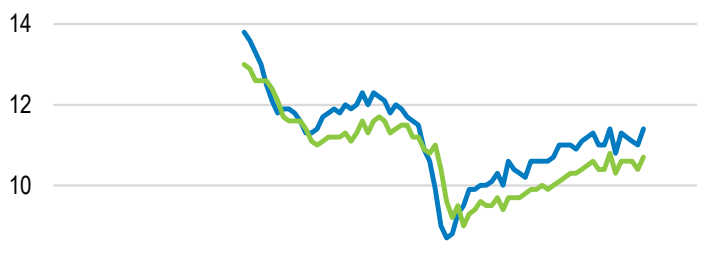

8

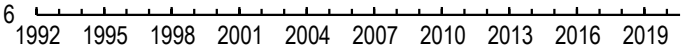

F. Job Openenings and Labor Turnover Survey (JOLTS)

\section{Percentage}

$6 \longrightarrow$ Job hire Job separations

5.5
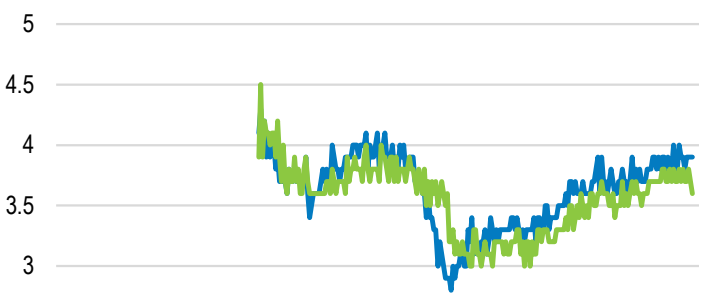

2.5

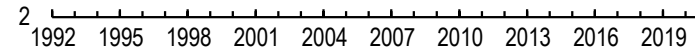

Note: The BDS data measure annual net change in employment at the establishment level for the private non-agricultural sector sourced from the business register. Job creation and destruction reflect expanding and contracting establishments as well as employment change from opening and closure. The BDM data measures and coverage are similar to those in BDS, but are available at quarterly rate and are compiled from administrative records for unemployment insurance. The QWI and J2J data measure quarterly job hire and job separations by tracking workers moving into and out of nonemployment and changing employers, sourced from the linked employer-employee LEHD data (cf. Section 0). The CPS tracks workers as well, but at monthly rate and is sourced from representative household surveys. Job-to-job transitions are included using the estimates by Fallick and Fleichman (2004). The JOLTS data measure monthly job hire and job separations tracking individual workers as well, but are based on an establishment survey.

Source: Census Bureau; BLS; Fallick and Fleischman (2004). 


\section{Job hire and job separation rates have declined}

12. According to the $\mathrm{J} 2 \mathrm{~J}$ data, job hire and separation rates have declined from around $13 \%$ of employment each quarter in the early 2000 s to around $11 \%$ in the late 2010 s (Figure 1 , Panel D). While a sizeable recovery was observed during the expansion following the global financial crisis, it is noteworthy that the rates were still below the levels observed before.

13. Job-to-job hires account for around half of all hires and display much more cyclical variation than hires from nonemployment (Figure 2, Panel A). A job-to-job move is defined as a transition from one job to another job with no or only a brief period of nonemployment. It can reflect both voluntary quits and layoffs followed by short and successful job search. In 2016-2018, the job-to-job hire rate had recovered to its peak level prior to the global financial crisis (Panel A). By contrast, hires from nonemployment have been on a downward trend from around $6 \%$ of employment each quarter in the mid-2000s to around $5 \%$ in 2018 , only interrupted by a drop during the global financial crisis. The development of job separations mirrors that of job hires (Panel B), except for differences in levels reflecting employment growth (reduction) in expansions (contractions).

\section{Figure 2. The decline in job mobility mainly reflects fewer hires from nonemployment}

Job hire and job separations in percent of total employment

\section{A. Job hire}

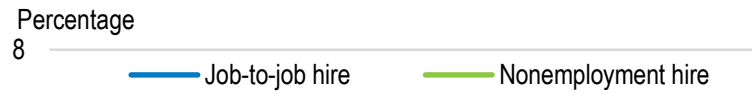

7

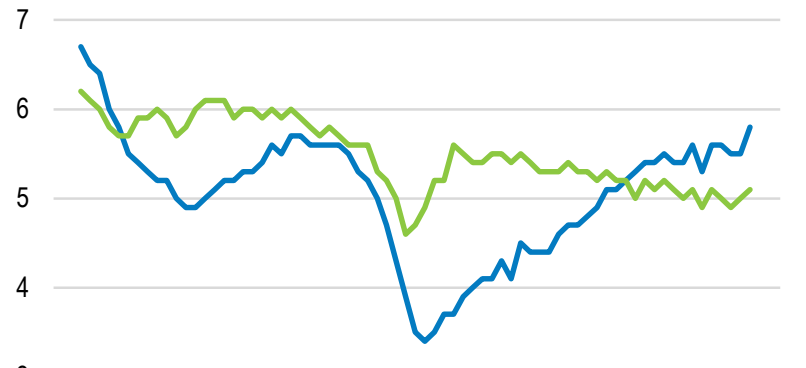

3

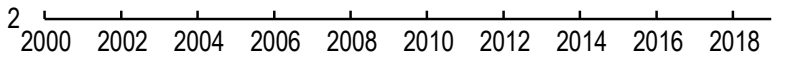

B. Job separation

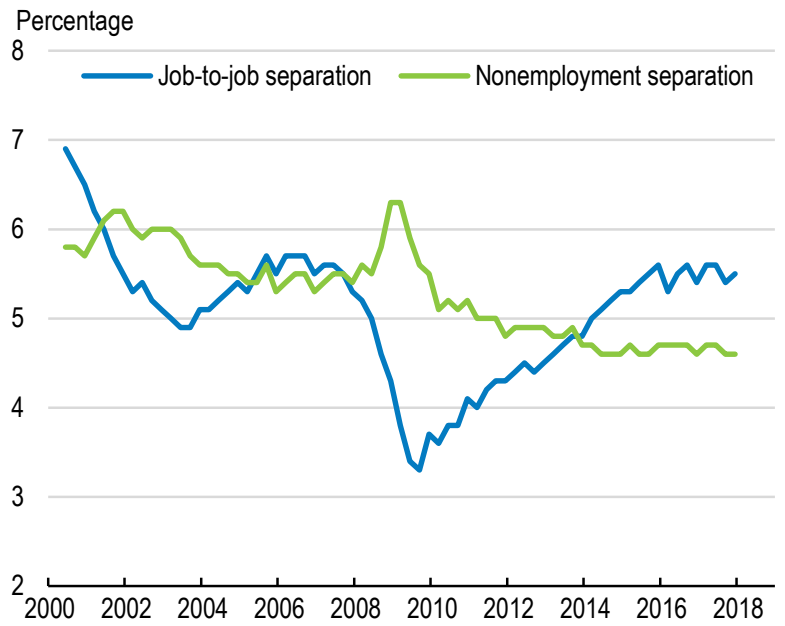

Note: The hire (separation) rate is defined as the number of hires (separations) divided by the average of total employment in the beginning and end of the quarter. Nonemployment refers to lack of a main job for at least a quarter, i.e. in unemployment or out of the labour force.

Source: Job-to-Job Flows database, Census Bureau. 
Figure 3. Job mobility and its development varies across age groups

A. Youth (age 14-24)
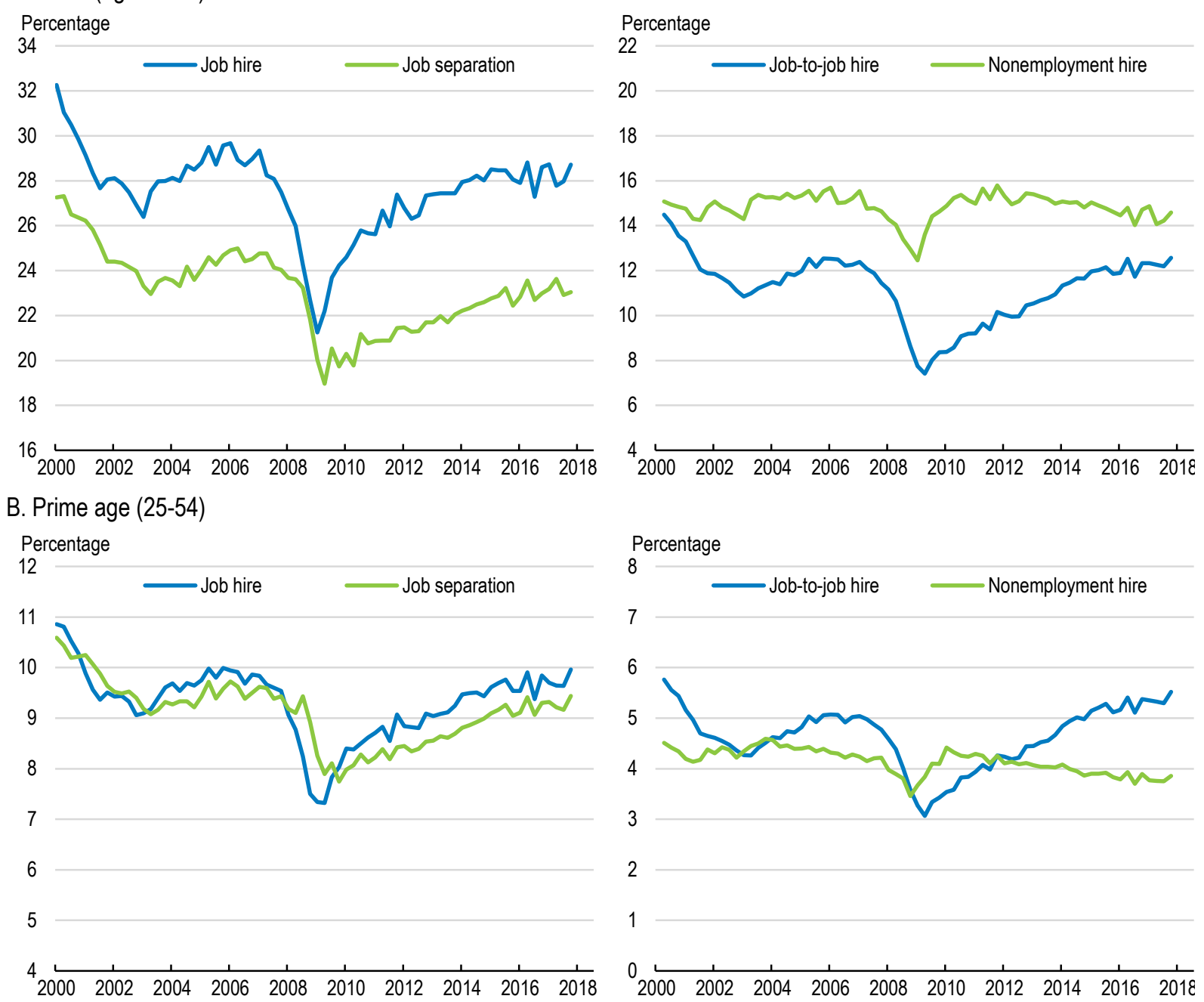

C. Seniors (age 55+)
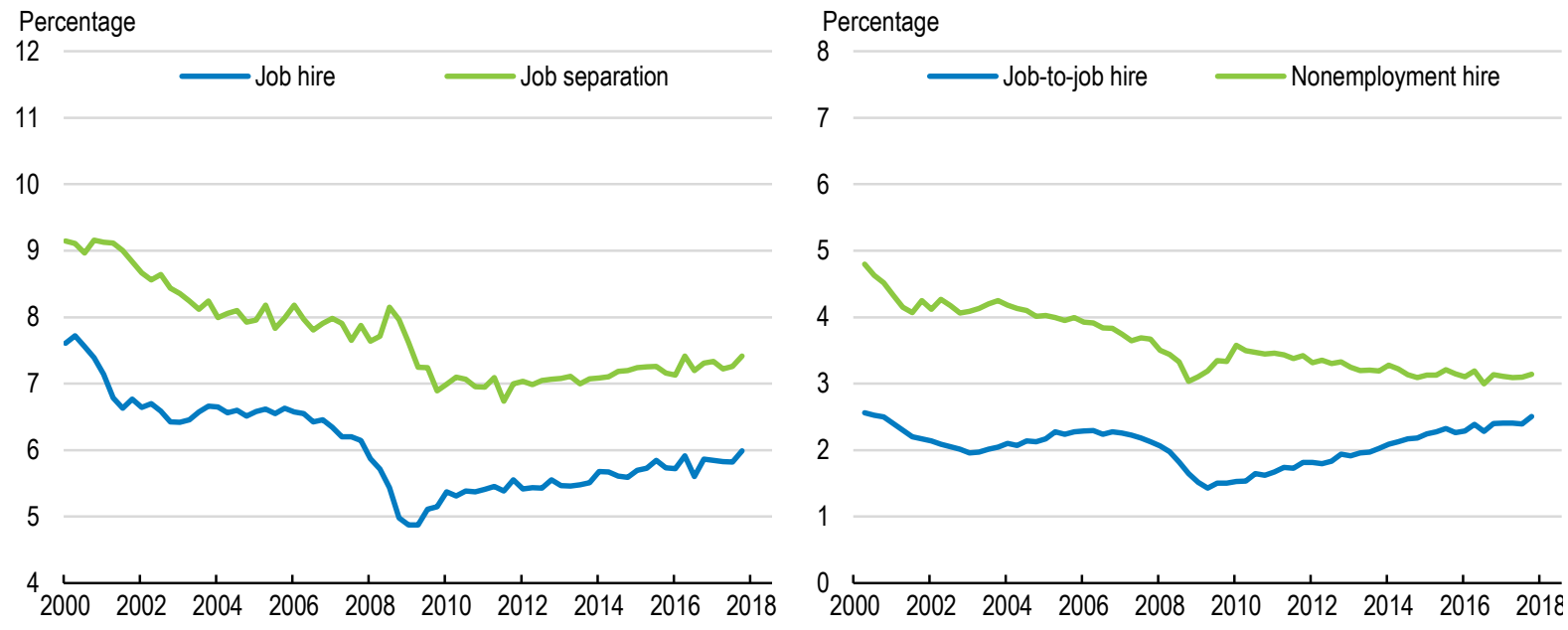

Note: Percentage of the employment stock in each age group.

Source: OECD calculations based on Job-to-Job Flows database, Census Bureau. 
14. Job mobility varies substantially across age groups, reflecting the different stages of a working life. The hire rate is very high and substantially above the separation rate among youth entering the labour market, and thereby dominated by hires from nonemployment (Figure 3, Panel A). Hires and separations tend to balance for prime age (age 25-54) for which job-to-job hires usually exceeds nonemployment hires (Panel B). Separations are well above hires among seniors (age 55+) who eventually exit the labour market, while the advanced career stage implies little mobility reflected by a low job-to-job hire rate (Panel C).

15. The three broad age groups have all experienced declining job hire and separation rates since the early 2000s. A notable exception is the job-to-job hire rate for the prime age group, which during 20152018 exceeded the level observed prior to the great recession. For seniors, increasing labour market participation and postponed retirement over recent decades are reflected in a secular decline in job separations. The strong rise in senior employment will likewise tend to drive down the job hire rate, even though the number of hires is rising (denominator-effect). The rising share of seniors in the working-age population and their lower labour market mobility can thus explain a substantial part of the aggregate decline in labour market fluidity (see Section 0 ).

16. Even so, a decline in hires from nonemployment to lower levels than in previous economic upturns is present across all age groups, suggesting other factors are important too. Recent work by Haltiwanger and Spletzer (2020) also point to an especially large decline in hires from non-employment. They find evidence of a changing labour market, making it more difficult to get onto the job ladder. Changing jobs and mobility patterns have also been analysed by Autor (2019), stressing marked differences across different skill groupings.

\section{Youth, low-skilled and young firms have the highest job hire rates}

17. Job-to-job moves are particularly important for youth as a means to move up the job ladder once they have entered the labour market (Haltiwanger et al., 2018). Youth aged 14-24 accounts for almost a third of all job-to-job moves, but less than $15 \%$ of total employment (Table 1). See Table A.1-Table A.3 in Annex for the distribution of job-to-job hires and employment across gender, education and race/ethnicity.

\section{Table 1. Youth make up a substantial share of job-to-job moves}

Percentage, average 2000 Q2-2018 Q1

\begin{tabular}{l|r|r|r|r}
\hline & Age 14-24 & Age 25-54 & Age 55+ & Total \\
\hline Share of job-to-job hire & 30.2 & 62.1 & 7.7 & 100 \\
\hline Share of employment & 13.6 & 67.8 & 18.5 & 100 \\
\hline
\end{tabular}

Source: OECD calculations based on Job-to-Job Flows database, Census Bureau.

18. Low-skill industries such as administration and support (e.g. cleaning, office and transportation support services), agriculture and accommodation and food have the highest job hire rates around $20 \%$ of employment per quarter, with more than half from nonemployment (Figure 4). In contrast, utilities, public administration and manufacturing have much lower job hire rates around $5 \%$ of employment per quarter. The highest share of job-to-job hires in total hires is in finance $(60 \%)$. A similar pattern holds across industries for job separations (not shown). 


\section{Figure 4. Job hires from nonemployment dominate in low-skill industries}

Job hire rates by industry, average 2000 Q2-2018 Q1

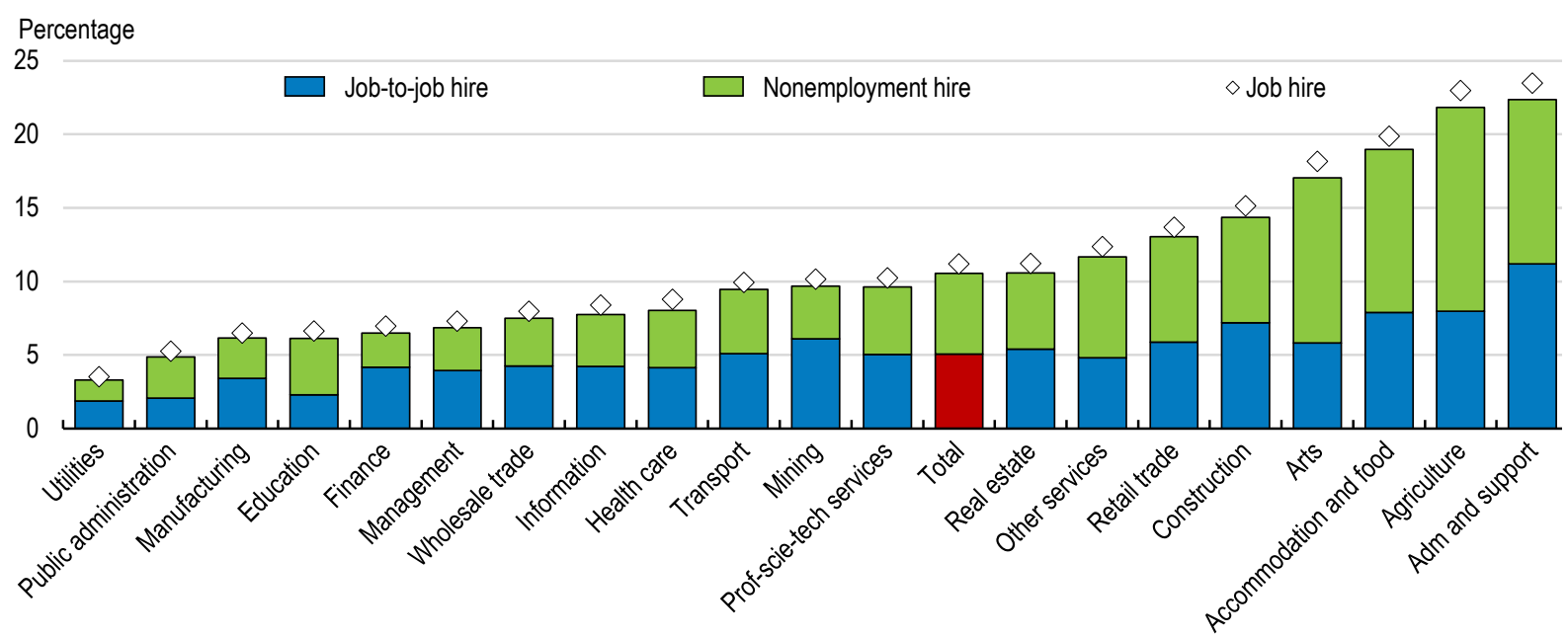

Note: The job hire rate is the sum of job-to-job hire and nonemployment hire plus a small residual reflecting hire to a new main job, while maintaining a previous main job as a secondary job.

Source: OECD calculations based on Job-to-Job Flows database, Census Bureau.

19. Across worker and firm characteristics, the largest job hire rates are observed among more disadvantaged groups (youth, non-whites, the less educated and those in young firms) (Figure 5). These results are simply conditional means (technically a marginal effect), reflecting the average job hire rate for the group after controlling for basic observable factors. Specifically, the estimates are obtained from an OLS regression with job-to-job (nonemployment) hire rates as the dependent variable and indicator controls for the worker and firm characteristics of interest as well as fixed effects for industry, State and time and unemployment rates at the State level. Separate regressions are applied for sex/age; race/ethnicity; sex/education; firm age; and firm size, keeping in mind the structure of the $\mathrm{J} 2 \mathrm{~J}$ data.

20. While the data do not allow for distinguishing the labour contract type of hires, many of the hires for the disadvantaged groups are likely to reflect temporary employment. Moreover, since these groups generally have the lowest employment rates, a denominator effect will also tend to increase their job hire rates. For instance, employment among age 14-18 is very modest, implying that few hires will result in a very high job hire rate. For these reasons, high job mobility among disadvantaged groups can reflect precarious work with low job security and poor compensation (fixed term contracts; seasonal, interim and gig workers). ${ }^{4}$ Mobility between such unstable jobs is less likely to be associated with economic benefits and contrasts with mobility that reallocates workers from low to high productivity firms and results in gains for both employers and employees. The bottom line is thus that job mobility needs to be balanced against other labour market outcomes as well (OECD, 2018a; Garnero et al., 2019), including the associated change in earnings from job-to-job moves.

\footnotetext{
${ }^{4}$ Note that since the $\mathrm{J} 2 \mathrm{~J}$ data are based on administrative records from State Unemployment Insurance, a large share of non-standard employment, e.g. self-employed, is excluded from the data.
} 
Figure 5. Who has the largest job hire rates?

Estimated marginal effect of worker and firm characteristics, percentage of employment, 2000 Q2-2018 Q1

A. Job-to-job hire rate

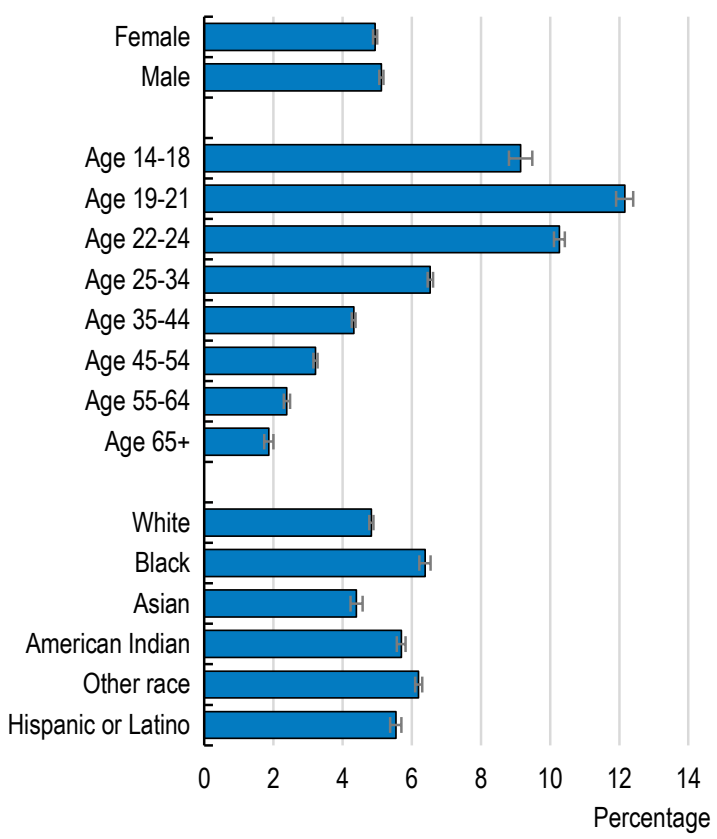

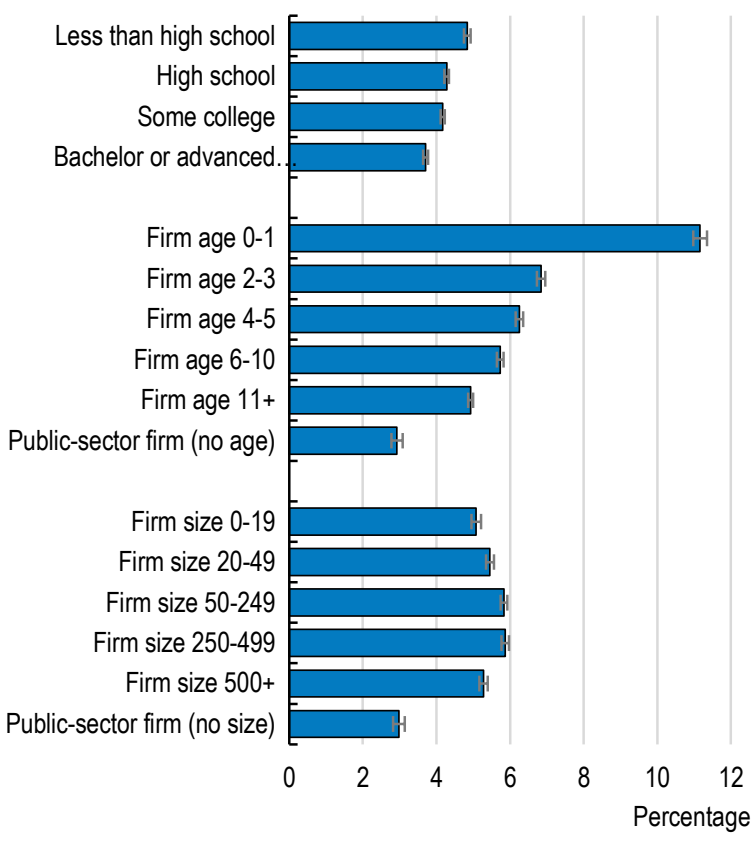

B. Nonemployment hire rate

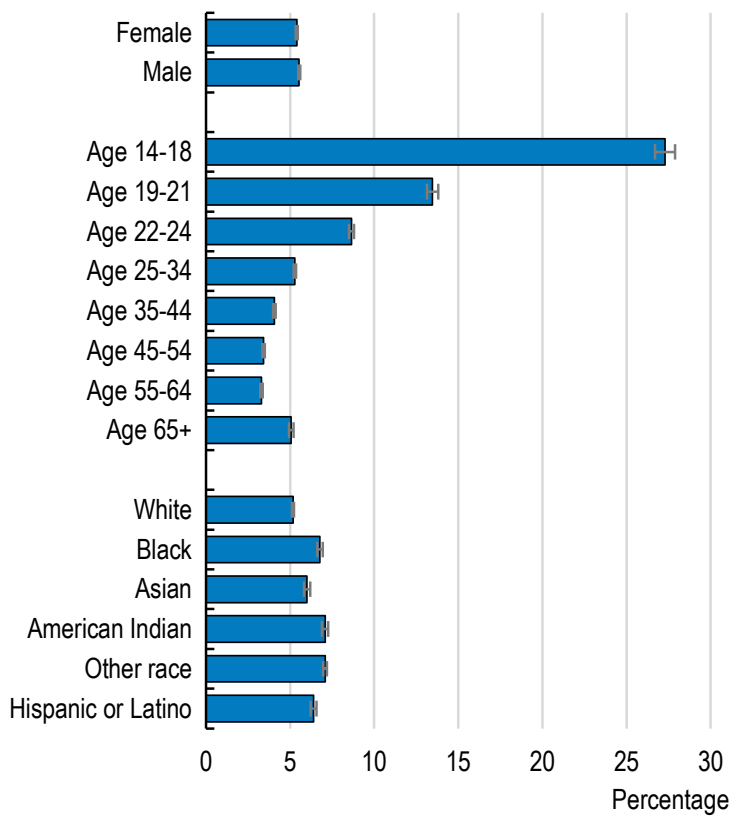

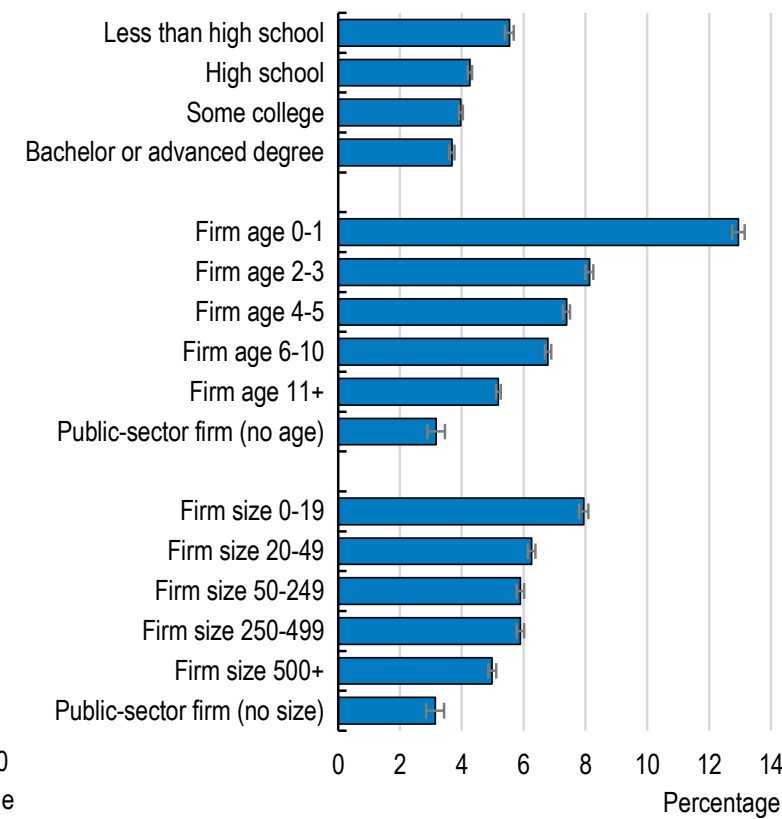

Note: The bars reflect the marginal effects (i.e. conditional means) from a regression of job-to-job (nonemployment) hire rates on indicators for the reported worker and destination firm characteristics as well as controls for State unemployment rates, industry, State and time fixed effects. Separate estimations are applied for sex/age; race/ethnicity; sex/education; destination firm age; and destination firm size. Error bands report $95 \%$ confidence intervals.

Source: OECD calculations based on Job-to-Job Flows database, Census Bureau. 


\section{Earnings for disadvantaged groups are boosted by job-to-job moves}

21. On average, job-to-job moves among disadvantaged groups (youth, non-whites and less educated) are associated with sizeable gains in gross quarterly earnings, exceeding those of other groups in relative terms (Figure 6). This holds both for job-to-job moves within the same quarter (Panel A) and moves with the new job starting the subsequent quarter, thus including a brief nonemployment period (Panel B). The average increase is about $12 \%$ for job moves within quarter, while workers below the age of 25 experience earnings gains of more than $20 \%$. Moreover, the data show that the average earnings change from a job-to-job move increases with the age and the size of the destination firm. This is in line with the robust empirical finding that larger businesses pay higher wages (e.g. Barth, Davis and Freeman, 2018). ${ }^{5}$

22. Across all worker characteristics, the average earnings increase is much lower when the job-tojob move includes a brief nonemployment period, e.g. $5 \%$ for females and $6 \%$ for males, suggesting that this type of job-to-job move includes many involuntary quits. After some time in unemployment, workers will tend to reduce their reservation wage and accept jobs with lower earnings compared to the previous job. The two types of job-to-job moves (with and without nonemployment period) may thus offer a firstorder approximation of voluntary and involuntary job transitions.

23. The earnings assessment has two main caveats. First, the earnings measure do not account for changes in hours worked, implying a mechanical boost in earnings if the job-to-job move involves a change from part-time to full-time work. For instance, the comparatively weak earnings return for seniors aged 5564 can be partially explained by many job moves to employment with reduced hours (Figure 6). Second, the assessment is descriptive (conditional means from a simple regression) and reflects the outcome of those who actually made a job transition (selection). The expected return to a job-to-job move for a random worker with the given characteristics will therefore be different. Nevertheless, the exercise suggests that job mobility is not only an important driver of productivity growth as shown in the literature (Decker et al., 2017; Foster et al., 2016); observed job-to-job moves are also on average associated with important movements up the job ladder in terms of earnings, especially for the disadvantaged groups (Haltiwanger et al., 2018).

24. The earnings increase associated with job-to-job moves, computed as the growth in earnings from the old to the new job, exceeds average earnings growth among job stayers by almost a factor ten (Figure 7). Across worker characteristics, it is noteworthy that higher-educated job stayers have the largest average earnings growth. Black workers experience the lowest earning growth among job stayers across race and ethnicity, contrasting the pattern for job-to-job moves. The reported real earnings growth for job stayers are nevertheless sizeable, with 0.01 and 0.012 log points increases per quarter on average for females and males roughly corresponding to $4.1 \%$ and $4.7 \%$ annual real growth, respectively. This is well above other measures of average earnings growth (e.g. BLS survey-based measures), which reflects that earnings information is only available for a selected group of stable job stayers (employed at least four consecutive quarters) and not being able to control for changes in hours worked.

\footnotetext{
${ }^{5}$ The structure of the $\mathrm{J} 2 \mathrm{~J}$ data do not allow controlling for firm size in the same regressions as firm age (and vice versa). Increasing earnings returns to firm age may thus reflect positive correlation between firm size and firm age.
} 
Figure 6. Who gains the most from job-to-job moves?

Estimated marginal job-to-job earnings growth effect of worker and firm characteristics, 2000 Q2-2018 Q1

A. Job-to-job move with no nonemployment period (job move within quarter)
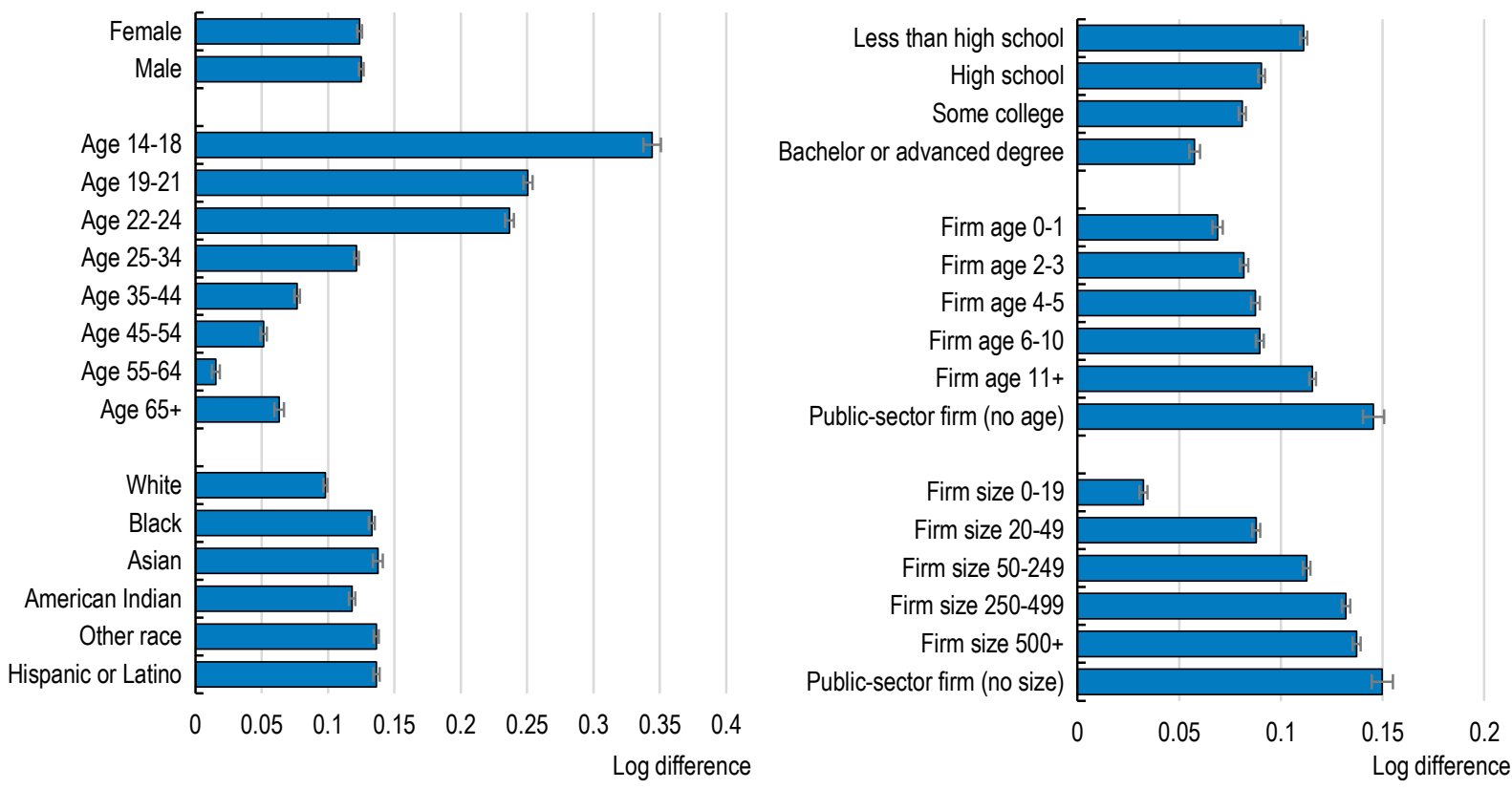

B. Job-to-job move with brief nonemployment period
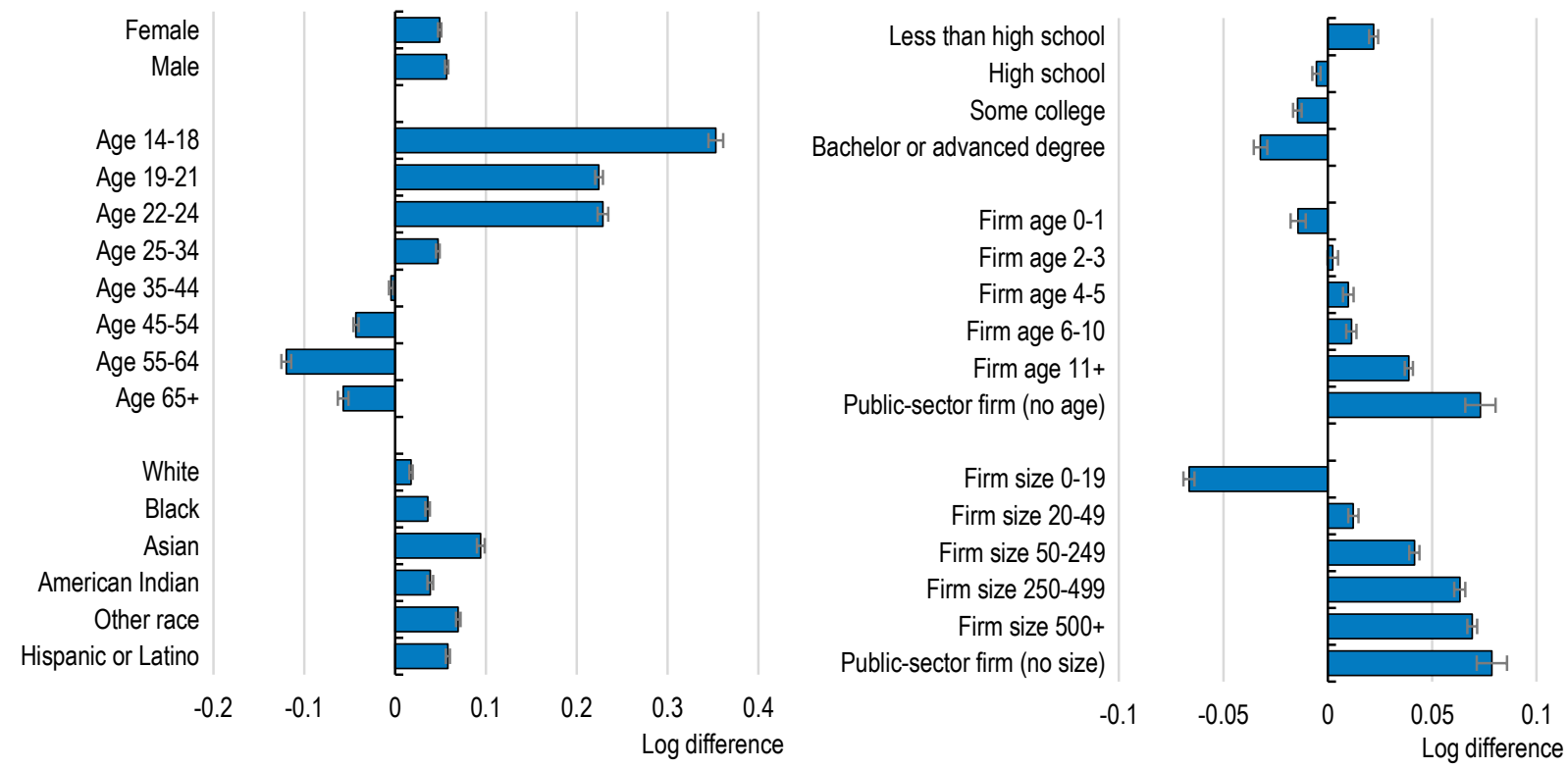

Note: Earnings are deflated by the PCE deflator. The bars reflect the marginal effects (i.e. conditional means) from a regression of the change in average earnings (log difference) from job-to-job move on indicators for the reported worker and firm characteristics as well as controls for within/between State move, State unemployment rates, industry, State and time fixed effects. Earnings are measured the quarter before (t-1) and after ( $t+1$ in Panel $A$ and $t+2$ in Panel $B$ ) the quarter of the move ( $t)$. Separate estimations are applied for sex/age; race/ethnicity; sex/education; firm age; and firm size. Error bands report $95 \%$ confidence intervals.

Source: OECD calculations based on Job-to-Job Flows database, Census Bureau. 


\section{Figure 7. Which job stayers have the largest average earnings growth?}

Estimated marginal effect on job stayer earnings growth of worker and firm characteristics, 2000 Q2-2018 Q1
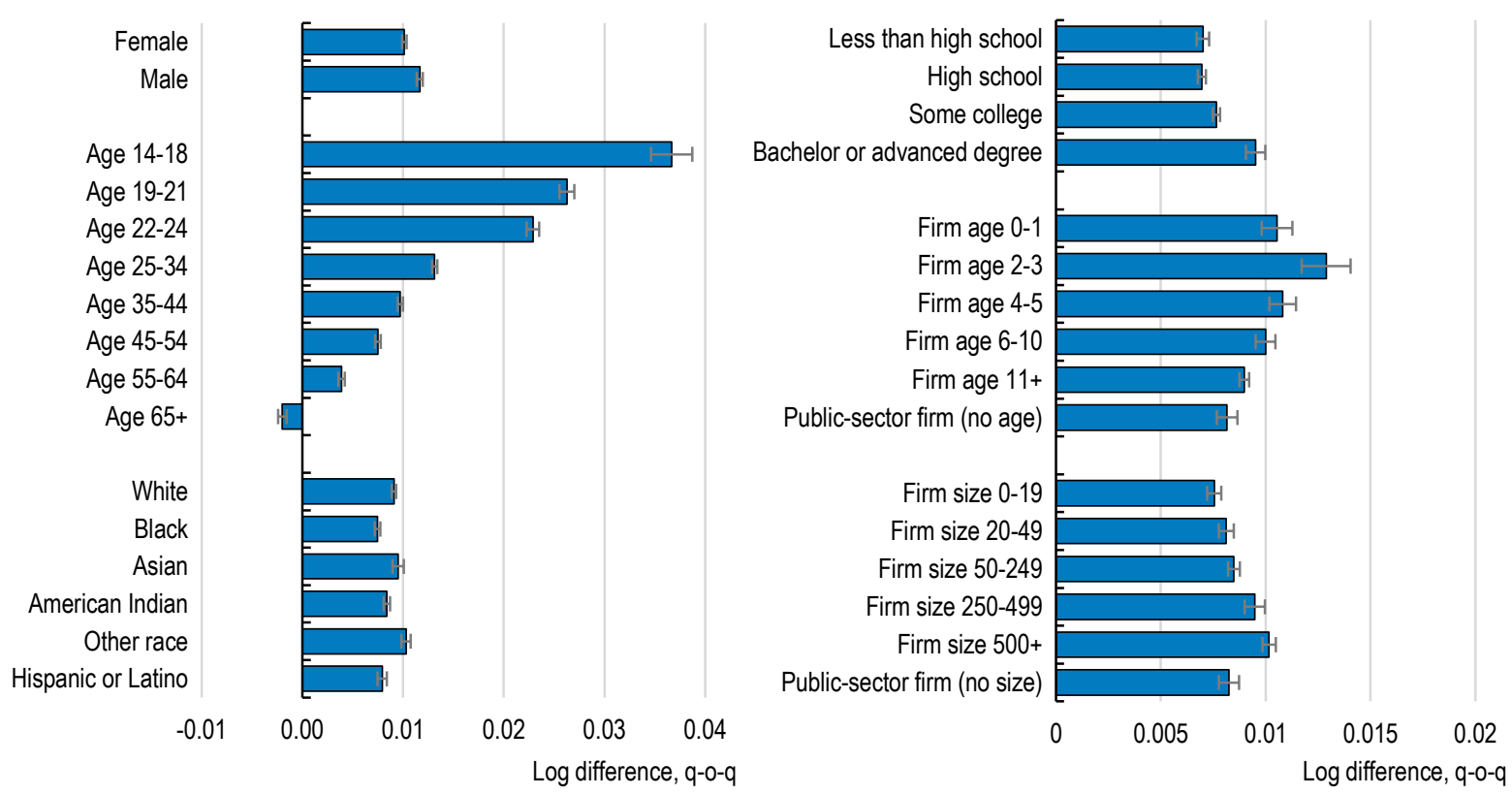

Note: Earnings are deflated by the PCE deflator. The bars reflect the marginal effects (i.e. conditional means) from a regression of the quarteron-quarter average earnings growth (log difference) for stable job stayers on indicators for the reported worker and firm characteristics as well as controls for State unemployment rates, industry, State and time fixed effects. Separate estimations are applied for sex/age; race/ethnicity; sex/education; firm age; and firm size. Error bands report 95\% confidence intervals.

Source: OECD calculations based on Job-to-Job Flows database, Census Bureau.

\section{The spatial dimension of job mobility}

25. Declining interstate migration and local concentration of joblessness in the United States motivate a more detailed examination of the development in spatial job mobility. This section focuses on the State level and interstate job-to-job moves in particular. However, the population has become increasingly concentrated in large metropolitan areas, which are better suited for in-depth analysis of spatial economic development. A recent paper provides novel insights by grouping metropolitan areas according to their labour market performance (Azzopardi et al., 2020).

\section{Interstate job-to-job moves tend to go West and South}

26. The Mountain and some Southern States have the highest job hire rates, while New England and some Midwest States have the lowest rates (Figure 8) (see Figure A.5 for a split in job-to-job and nonemployment hire rates). Areas with strong population growth will also tend to have high job hire rates unless groups not in the working-age drive population growth. As a result, State population growth and average job hire rates are positively correlated (Figure 9). 
Figure 8. Mountain States have the highest job hire rates

Average job hire rate, 2010 Q2-2016 Q1

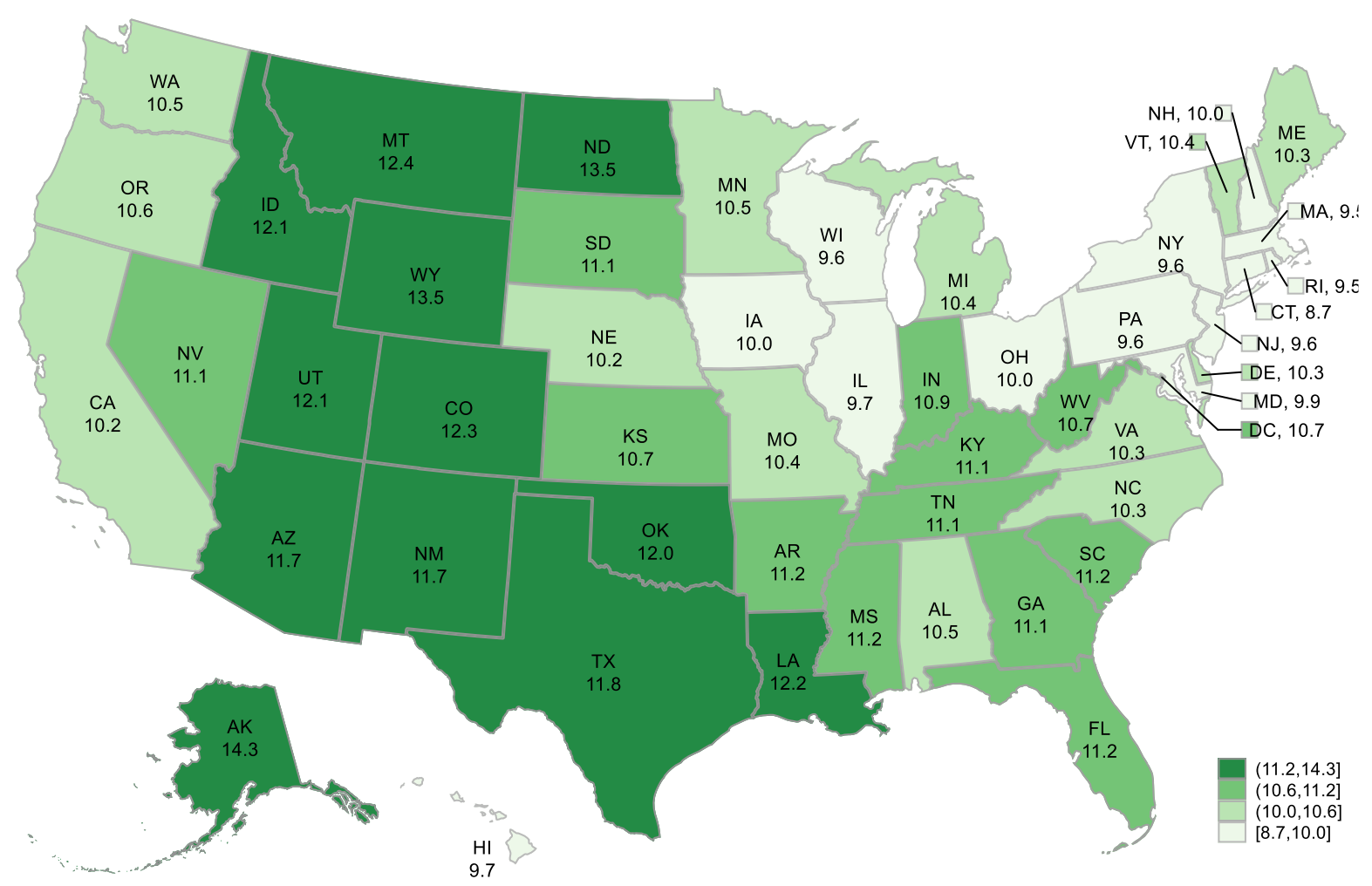

Note: Total job hires, including nonemployment hires and job-to-job hires from within and out-of-State, by quarter in per cent of State employment. Source: OECD calculations based on Job-to-Job Flows database, Census Bureau.

Figure 9. Job hire rates are positively associated with population growth

Population growth and job hire, 2010-2016

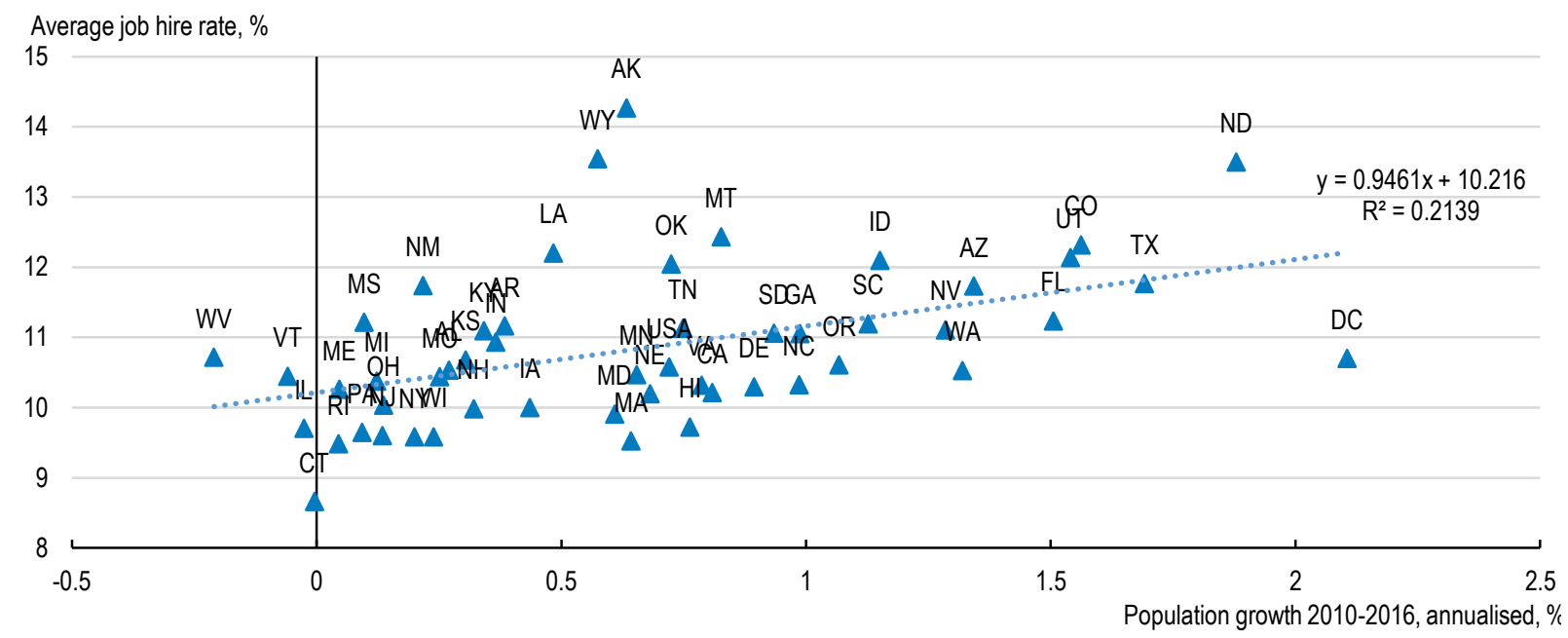

Source: OECD calculations based on Job-to-Job Flows database and Population estimates, Census Bureau. 
27. The gross inflows and outflows of job-to-job movers vary substantially across States (Figure 10), not least because of differences in State sizes. California and Michigan had the lowest inflow and outflow in per cent of State employment, whereas North Dakota and Wyoming had the largest during 2010-2016. ${ }^{6}$ In net terms, Western and Southern States have tended to gain employment from interstate job-to-job moves, while the Northeast and many Midwest States have experienced net losses (Figure 11). The largest net loss was recorded in Mississippi with $-0.5 \%$ of employment annually during 2010-2016, while the shale oil boom in North Dakota resulted in the highest annual net inflow of $1.7 \%$ of employment.

28. The movement towards Southern and Western States is a decade-long trend, reflecting multiple factors, not least better job opportunities as manufacturing contracted in the Midwest and services and high-tech jobs boomed elsewhere (Sutherland, 2020). Other important drivers are changing preferences for a warmer climate and lower costs of living.

\section{Figure 10. Annual interstate job-to-job moves is close to $5 \%$ of employment in many States}

Annual cumulated job-to-job in- and outflows 2010 Q2-2016 Q1, per cent of State employment

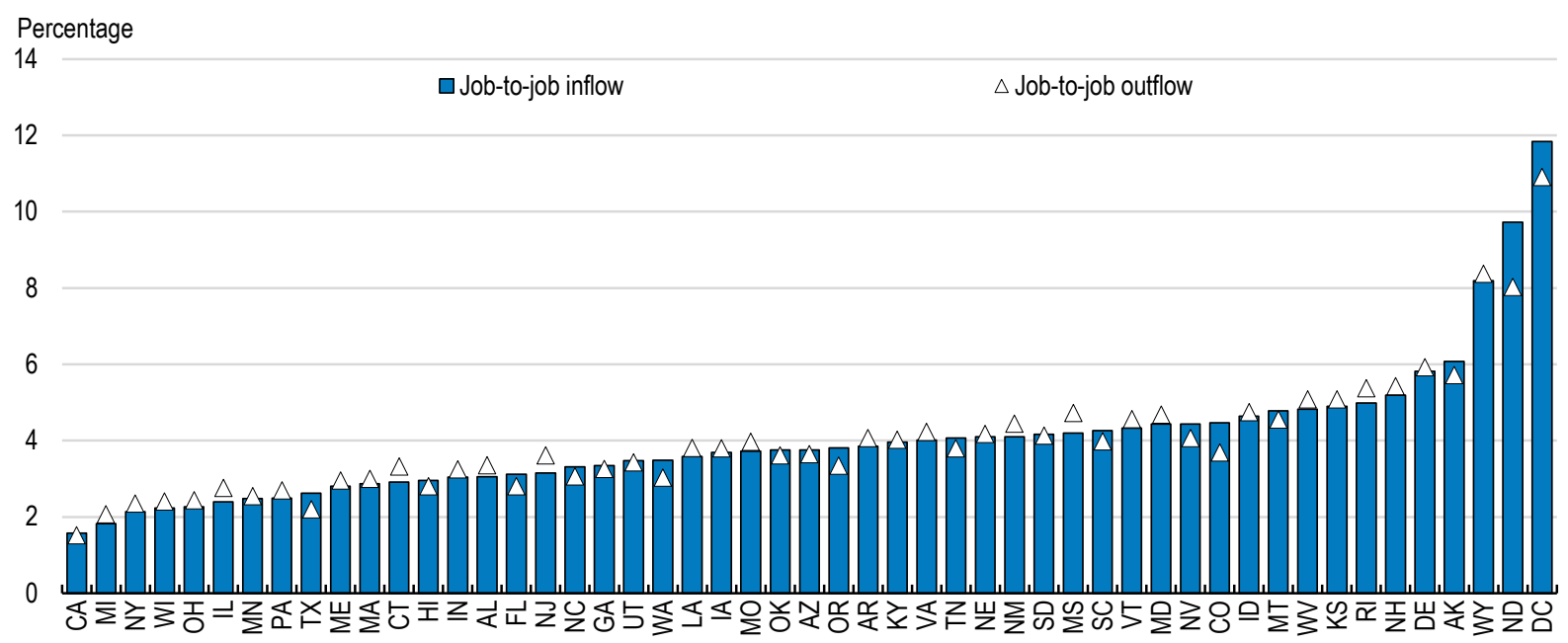

Note: Includes job-to-job hires with and without brief nonemployment.

Source: OECD calculations based on Job-to-Job Flows database, Census Bureau.

\footnotetext{
6 The very high inflow and outflow in District of Columbia reflects the integration with Maryland and Virginia in the Washington Metropolitan area.
} 
Figure 11. Net job-to-job moves tend to go West and South

Annual net job-to-job inflow 2010 Q2-2016 Q1, per cent of destination State employment

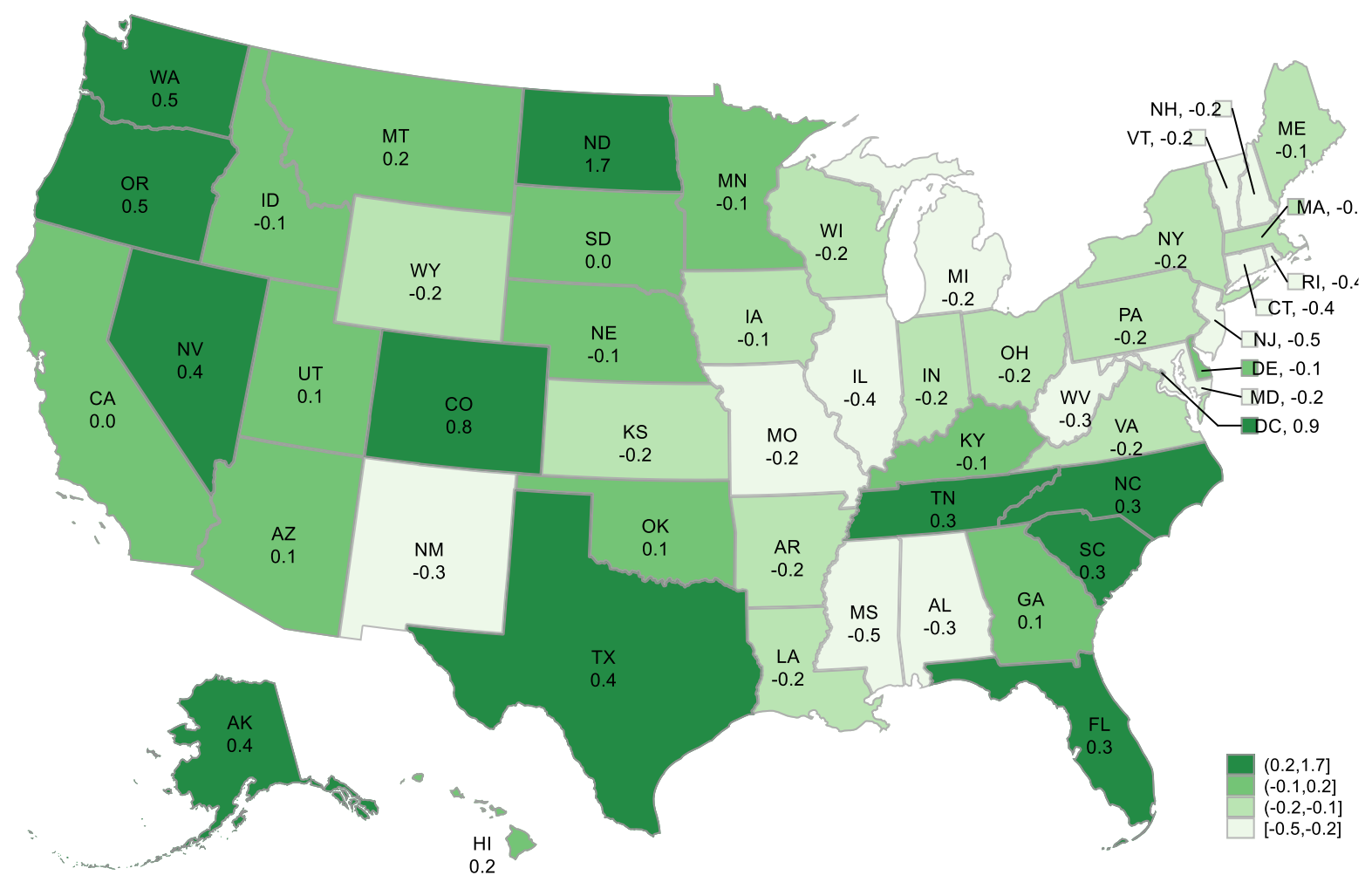

Note: Difference between job-to-job inflows and outflows illustrated in Figure 10.

Source: OECD calculations based on Job-to-Job Flows database, Census Bureau.

29. The job movers to the West and South come from all regions of the United States (Table 2). While there is a net flow in this direction, others move in the opposite direction and in all regions, more than $90 \%$ of all job-to-job moves take place within the region. From the Northeast region, $91 \%$ of job-to-job movers stayed in the region; $1.5 \%$ went to the Midwest; $5.5 \%$ to the South and $2 \%$ to the West during $2010-2016$ (Panel A). Towards the West region, 92\% came from a job within the West; almost $4 \%$ came from the South; 2.4\% from the Midwest and 1.4\% from the Northeast during 2010-2016 (Panel B). The largest flows of job-to-job movers across regions were between the South and the Midwest with $1.1 \%$ and $1.9 \%$ of all job-to-job moves in the United States in each direction, respectively (Panel C). This tabulation underscores that net job-to-job gains mask a substantial flow of workers across all regions and States each quarter. 
Table 2. Job-to-job moves across regions are much lower than mobility within regions

Percentage of all job-to-job hires by origin and destination region, average 2010 Q2-2016 Q1

\begin{tabular}{|c|c|c|c|c|c|}
\hline A. Origin region job-to-job distribution & \multicolumn{4}{|c|}{ Destination } & \multirow[b]{2}{*}{ Total } \\
\hline Origin & Northeast & Midwest & South & West & \\
\hline Northeast & 91.1 & 1.5 & 5.5 & 2.0 & 100 \\
\hline Midwest & 1.0 & 91.7 & 5.0 & 2.3 & 100 \\
\hline South & 1.8 & 2.5 & 93.6 & 2.1 & 100 \\
\hline West & 1.1 & 2.0 & 3.6 & 93.3 & 100 \\
\hline B. Destination region job-to-job distribution & \multicolumn{4}{|c|}{ Destination } & \\
\hline Origin & Northeast & Midwest & South & West & \\
\hline Northeast & 92.5 & 1.1 & 2.2 & 1.4 & \\
\hline Midwest & 1.5 & 92.6 & 2.8 & 2.4 & \\
\hline South & 4.5 & 4.4 & 93.0 & 3.7 & \\
\hline West & 1.5 & 2.0 & 2.0 & 92.4 & \\
\hline Total & 100 & 100 & 100 & 100 & \\
\hline C. National job-to-job distribution & \multicolumn{4}{|c|}{ Destination } & \\
\hline Origin & Northeast & Midwest & South & West & Total \\
\hline Northeast & 14.6 & 0.2 & 0.9 & 0.3 & 16.0 \\
\hline Midwest & 0.2 & 20.9 & 1.1 & 0.5 & 22.8 \\
\hline South & 0.7 & 1.9 & 36.9 & 0.8 & 39.5 \\
\hline West & 0.2 & 0.4 & 0.8 & 20.3 & 21.7 \\
\hline Total & 15.8 & 22.6 & 39.7 & 21.9 & 100.0 \\
\hline
\end{tabular}

Note: Includes job-to-job hires with and without brief nonemployment.

Source: OECD calculations based on Job-to-Job Flows database, Census Bureau.

\section{The interstate job-to-job hire rate has been stable}

30. Around $16 \%$ of all the recorded job-to-job moves in the $\mathrm{J} 2 \mathrm{~J}$ data are between employers located in different States (Table 3). While this is nontrivial, it is much more frequent to change industry than State. More than $60 \%$ of all job-to-job moves are between industries (at the 2-digit level), which nonetheless need not reflect a change in occupation (a secretary can for example find work in firms in many different industries). Unfortunately, the J2J data does not (yet) provide information by occupations to investigate this further. Previous evidence points to substantial occupational mobility in job-to-job moves as well (e.g. Kambourov and Manovskii, 2008)

\section{Table 3. More than half of all job-to-job hires is within States and between industries}

Distribution of job-to-job moves across the United States, 2010 Q2-2016 Q1

\begin{tabular}{l|r|r|r}
\hline & Within industries & Between industries & \multicolumn{1}{c}{ Total } \\
\hline Within States & 31.4 & 52.3 & 83.7 \\
\hline Between States & 7.3 & 9.0 & 16.3 \\
\hline Total & 38.7 & 61.3 & 100 \\
\hline
\end{tabular}

Note: Industries are defined at the 2-digit NAICS level. The time period is selected to have full coverage of all 50 States and District of Columbia. Source: OECD calculations based on Job-to-Job Flows database, Census Bureau.

31. The interstate job-to-job hire rate has remained relatively stable just below $1 \%$ of total employment per quarter since 2000 (Figure 12, Panel A). An interstate job move is however not the same as interstate 


\section{4 | ECO/WKP(2020)52}

migration as it may reflect commuting across a State border. Closer examination shows that almost half of all interstate job-to-job moves are between neighbouring States (Panel B), likely reflecting some commuting. While this decomposition could suggest that interstate job-to-job moves are trivial, especially those between distant States, it is useful to recall that $0.4 \%$ of employment per quarter corresponds to $1.7 \%$ per year and $8.8 \%$ of employment cumulated over five years.

\section{Figure 12. The interstate job-to-job hire rate has remained stable since early 2000}

Job-to-job hire by type of move, per cent of aggregate employment

A. Job-to-job hire

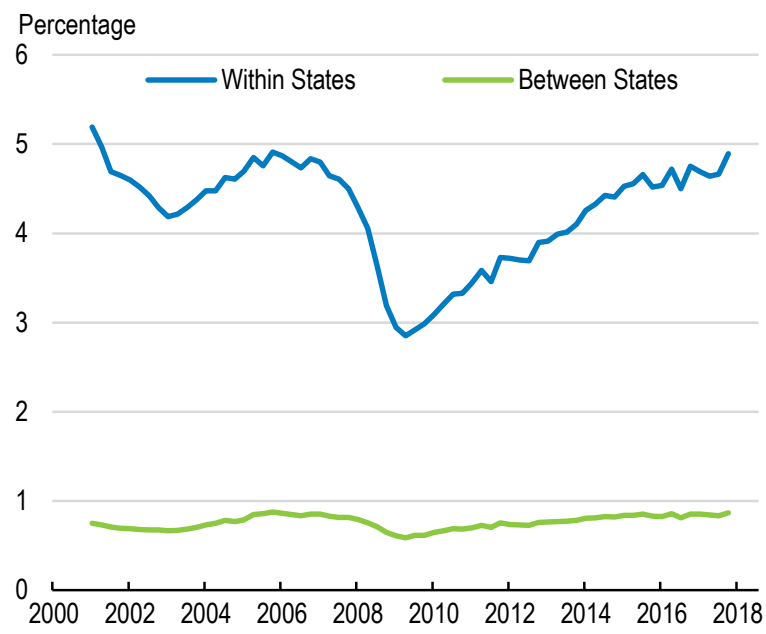

B. Job-to-job hire between States

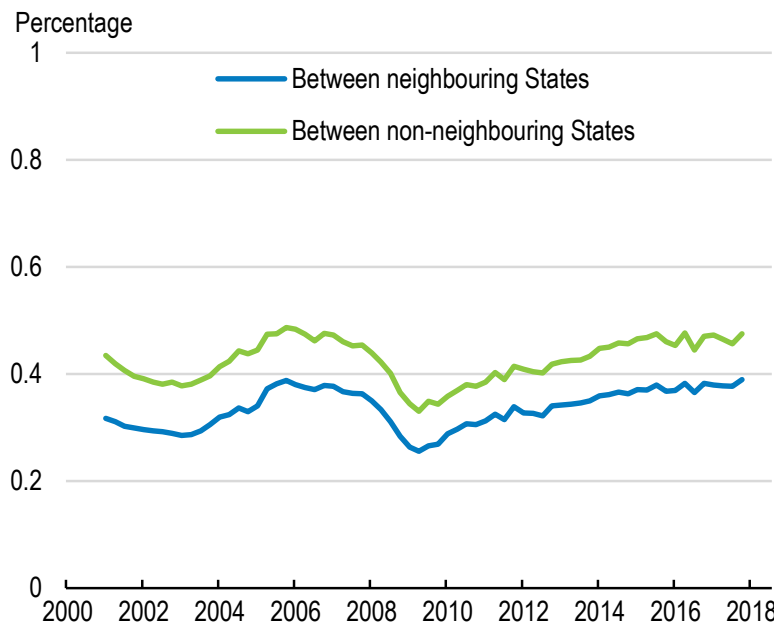

Note: Based on an unbalanced number of States over time. 36 States are available from 2001 Q2, gradually increasing to cover all 51 States from 2010 Q2. From 2016 Q2 and 2017 Q1 two States are missing. See Figure A.6 for a balanced version.

Source: OECD calculations based on Job-to-Job Flows database, Census Bureau.

32. The stable development in interstate job-to-job moves contrasts with the secular decline in the interstate migration rate recorded by the Current Population Survey (CPS) (see e.g. Molley et al., 2011; OECD, 2020). There are several explanations for this. First, migration for job-related reasons is only a small share of all interstate migration since e.g. students and retirees move frequently. Second, discrepancies between administrative and survey-based migration records are well-known (Hyatt et al., 2018). The sharp decline in survey-based interstate migration post-2000 is not observed in administrative data records (tax registers and the linked employer-employee data used in this paper). Closer examinations of the underlying micro-data have shown that an increasing share of CPS respondents do not report interstate moves, while they are recorded as interstate movers in the administrative data. The reasons for this are nevertheless unclear.

33. Interstate job-to-job hire rates vary across worker characteristics, but since the early 2000 , no subgroup has displayed substantial changes beyond cyclical fluctuations (Figure 13). Men and youth have the highest interstate job-to-job hire rates (Panels $A$ and $B$ ), while variation is much lower across education and race/ethnicity groups (Panels $\mathrm{C}$ and $\mathrm{D}$ ). However, black workers display more cyclical variation and reached a higher interstate job-to-job hire rate during 2016-2018 compared to the peak prior to the global financial crisis (Panel C). By contrast, Hispanic and Latino workers have the lowest interstate job-to-job 
hire rates, which although it declined by less than other groups during the global financial crisis it did not recover fully to the level observed in the mid-2000s. ${ }^{7}$

Figure 13. Men and youth have the highest interstate job-to-job hire rates

Interstate job-to-job hire rate by demographic and socioeconomic groups, per cent of employment
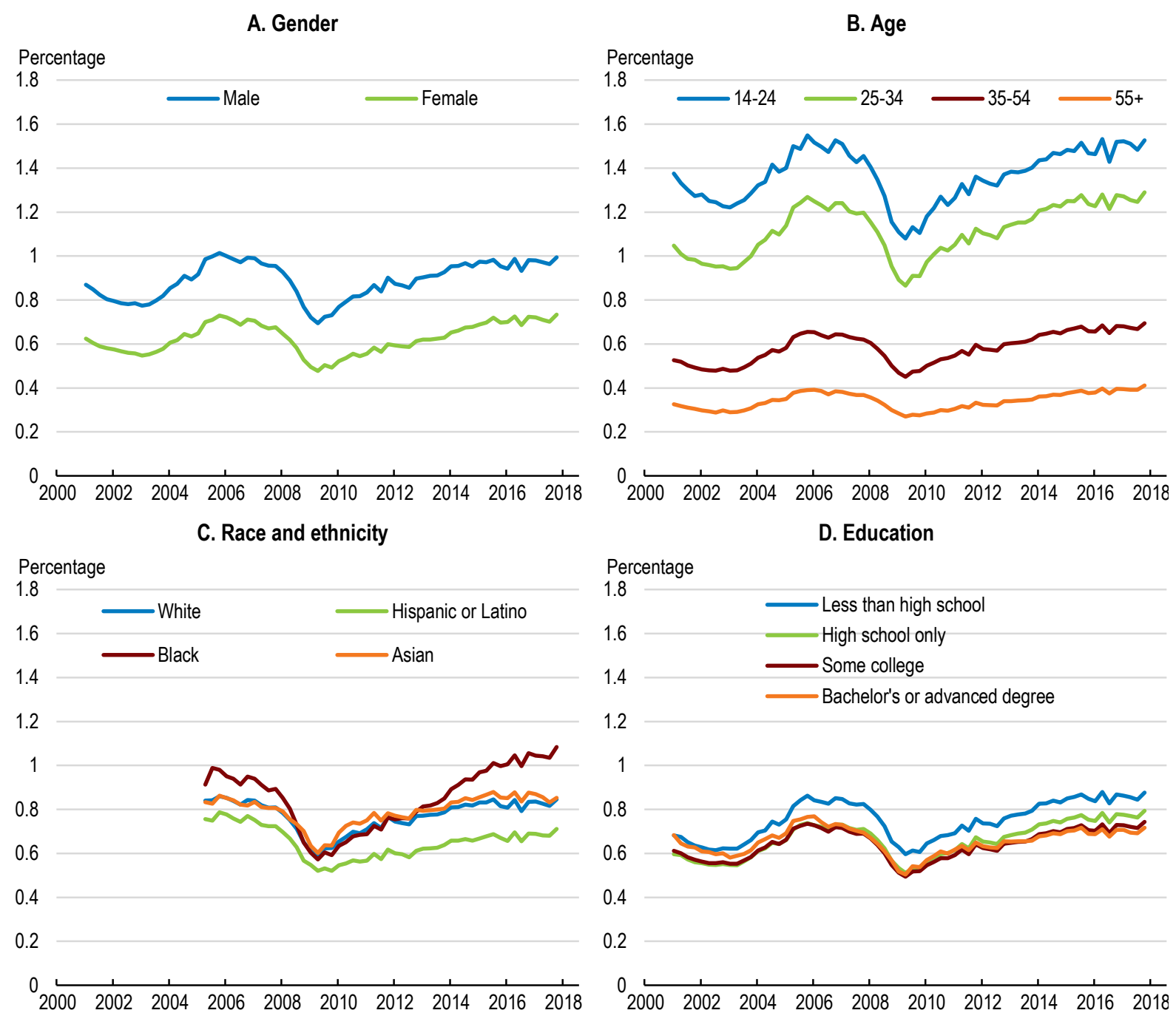

Note: Based on an unbalanced number of States over time. Observations prior to $2005 \mathrm{Q} 3$ are excluded for race and ethnicity due to the entry of Maryland and Virginia, which causes a break in the series for Blacks.

Source: OECD calculations based on Job-to-Job Flows database, Census Bureau.

34. While interstate job-to-job hire rates (i.e. share of employment) declines with age (Figure 13, Panel B), the interstate share of all job-to-job hires (i.e. odds ratio) increases with age (Figure 14). For youth, $12.5 \%$ of all job-to-job hires are between States, increasing to $17.4 \%$ for prime age and $21 \%$ for seniors. In other words, the frequency to change job declines with age, but it becomes more likely to move a longer

\footnotetext{
${ }^{7}$ A study of low-skilled Mexican-born immigrants found that this group displayed higher mobility than native-born in response to changing demand in local labour markets during the global financial crisis (Cadena and Kovak, 2016).
} 
distance in case of a job move (see Table A.4-Table A.6 in Annex for interstate job-to-job moves across gender, education and race/ethnicity).

\section{Figure 14. The share of job-to-job moves across States increases with age}

Distribution of job-to-job moves by age groups, 2010 Q2-2016 Q1

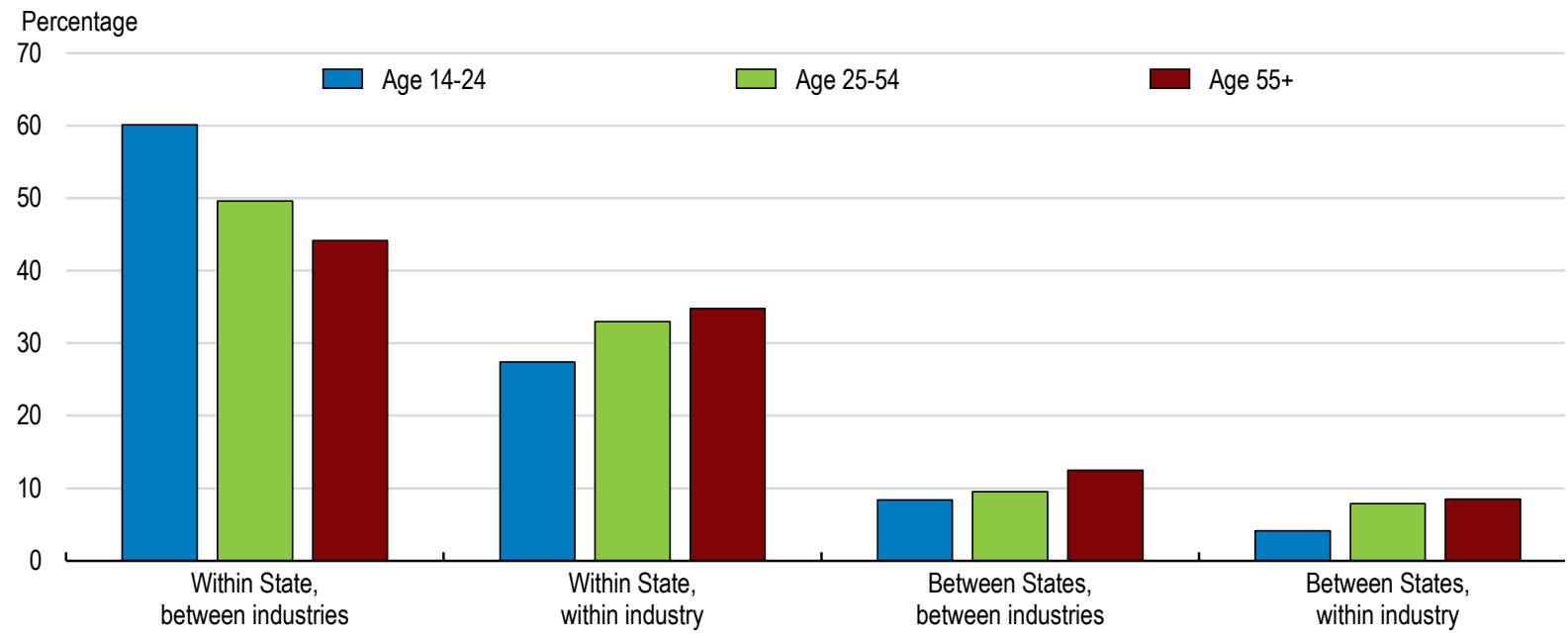

Note: Industries are defined at the 2-digit NAICS level.

Source: OECD calculations based on Job-to-Job Flows database, Census Bureau.

\section{Moving far for a job tends to be associated with a boost in earnings}

35. Workers moving longer distances and switching industries tend to benefit from a sizeable earnings boost (Figure 15). Earnings growth is about 4 percentage points (0.04 log points) higher for a job-to-job move between non-neighbouring States than moves within State (Panel A), both within and across industries. For job-to-job moves with a brief nonemployment period the difference is more than twice as high (Panel B). ${ }^{8}$ This assessment is based on observed job-to-job moves and naturally reflects that moving far away involves costs, such as being distant from family, and thus requires a higher compensation for workers to make such a choice (selection). ${ }^{9}$ Nonetheless, even moves between neighbouring States are on average associated with a substantial earnings gain compared to within State job-to-job moves, suggesting that higher geographic job mobility leads to better job matches and reallocation of workers from low to high productivity firms.

36. On average, the observed job-to-job moves from the Midwest to the Northeast yields the highest earnings boost across regions with $19 \%$, while the lowest payoff is observed for moves from the West to the South with $7 \%$ on average (Table 4). These are raw averages, ignoring differences in industrial structure and in the age and education of job-to-job movers. The dispersion is nonetheless sizeable.

\footnotetext{
${ }^{8}$ The difference could be boosted by a sorting mechanism since job-to-job moves with a brief nonemployment period likely compose a sizeable share of involuntary layoffs. While this group may search and find jobs within States, the between States job-to-job moves may still be mostly voluntary moves since geographical relocation can take time and extend the nonemployment period into the next quarter.

9 The brief nonemployment period may also reflect garden leave if workers have signed restrictive non-competition agreements (Hermansen, 2020). This could sort high wage workers into the group of interstate job-to-job movers with brief nonemployment period as they are more likely to sign such agreements.
} 
Figure 15. Moving farther away and switching industry is associated with earnings gain

Estimated marginal earnings effect from job-to-job move, average 2000 Q2-2018 Q1

A. Job-to-job move within quarter

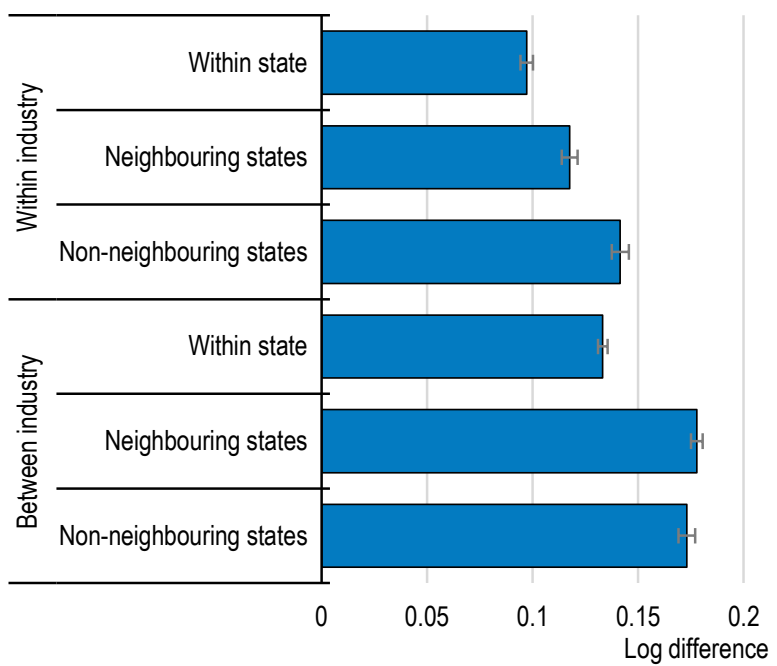

B. Job-to-job move with brief nonemployment

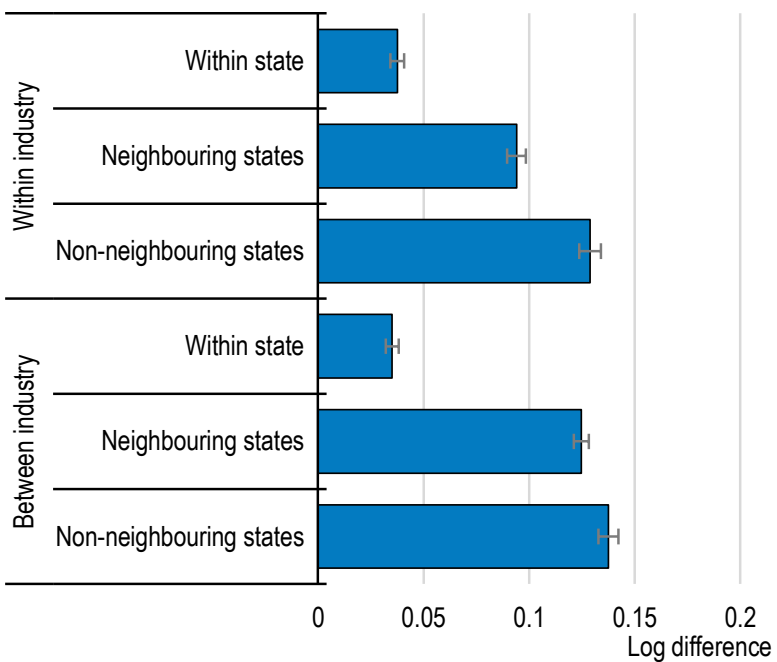

Note: Earnings are deflated by the PCE deflator. The bars reflect the marginal effects (i.e. conditional means) from a regression of the change in average earnings (log difference) from job-to-job move with controls for sex, age, industry, State and time fixed effects. Earnings are measured the quarter before ( $t-1)$ and after ( $t+1$ in Panel $A$ and $t+2$ in Panel $B$ ) the quarter of the move (t). Error bands report 95\% confidence intervals. Source: OECD calculations based on Job-to-Job Flows database, Census Bureau.

\section{Table 4. Job-to-job moves to the Northeast yields the highest earnings growth on average}

Average change in log earnings for job-to-job moves by origin and destination region, 2010 Q1-2016 Q2

\begin{tabular}{l|r|r|r|r}
\hline & \multicolumn{5}{|c}{ Destination } \\
\hline Origin & Northeast & Midwest & South & West \\
\hline Northeast & 0.11 & 0.12 & 0.08 & 0.13 \\
\hline Midwest & 0.19 & 0.12 & 0.12 & 0.15 \\
\hline South & 0.14 & 0.09 & 0.10 & 0.12 \\
\hline West & 0.10 & 0.08 & 0.07 & 0.09 \\
\hline
\end{tabular}

Note: Average across all job-to-job moves within and between States and with and without brief nonemployment. Earnings are deflated by the PCE deflator and measured between $\mathrm{t}-1$ and $\mathrm{t}+1$ (no nonemployment) or $\mathrm{t}+2$ (brief nonemployment).

Source: OECD calculations based on Job-to-Job Flows database, Census Bureau.

37. A simple time series plot of the earnings return to interstate job-to-job moves (dark red lines) indicates, beyond large cyclical fluctuations, an increase over time for all age groups (Figure 16). However, the change in earnings from job-to-job moves within States (green lines) tends to follow a similar trend, suggesting that the secular decline in job mobility (reduced supply) has been associated with a general increase in the return to job mobility (higher price). It is also noteworthy that the difference in returns to jobto-job moves within and between States (the gap between dark red and green lines) varies across age groups. This is partly a compositional effect since change of industry matters much for the return and its incidence varies across age groups (Figure 14). 
Figure 16. The job-to-job earnings return varies over the cycle and across age groups

Change in log earnings for job-to-job moves and job stayers
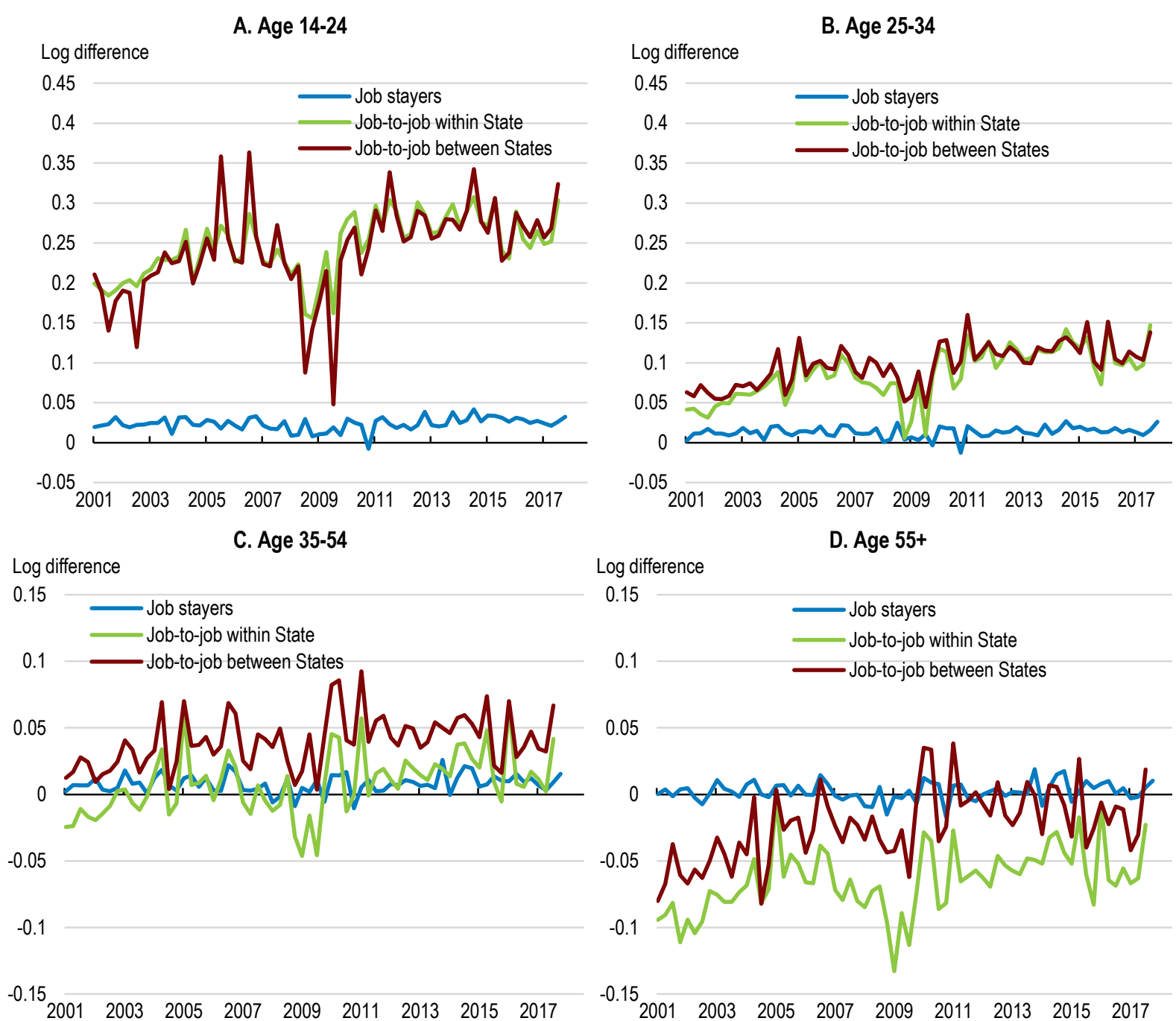

Note: Log difference between average earnings in $t$ and $t-1$ for job stayers; between $t+1$ or $t+2$ and $t-1$ for job-to-job moves (no or brief nonemployment period). Earnings are deflated by the PCE deflator.

Source: OECD calculations based on Job-to-Job Flows database, Census Bureau.

38. The earnings return to interstate job-to-job moves across age groups and over time is further analysed by simple regression analysis (see Table A.7 and Figure A.7 in Annex for a similar exercise across education groups). Table 5 reports earnings growth regressions for each age group with indicators for the six possible job-to-job moves presented above (Figure 15). Again, these results reflect simple correlations (conditional means) based on observed job-to-job moves and thus cannot be given a causal interpretation. Across all age groups, there is a positive earnings gain from moving to another State or switching industry (within State and within industry job-to-job move is the excluded category), except for seniors remaining in the State, but switching industry. Youth (age 14-24) changing both State and industry stand out with the highest average earnings increase of $18 \%-19 \%$. By contrast, the returns for the remaining age groups and combinations are generally in the range of $2 \%-6 \%$. These correlations suggest that all age groups on average experience an important earnings boost from an interstate job-to-job move and that this gain varies modestly across groups above 25 years of age. 
Table 5. All age groups have positive earnings returns from interstate job-to-job moves

Average earnings regressions by age groups, 2000 Q4-2018 Q1

\begin{tabular}{|c|c|c|c|c|c|c|c|c|}
\hline $\begin{array}{l}\text { Dependent variable: } \\
\text { Change in log earnings from job-to-job move }\end{array}$ & Age 14-24 & & Age 25-34 & & Age $35-54$ & & Age 55+ & \\
\hline \multicolumn{9}{|l|}{ Job-to-job move to: } \\
\hline Neighbouring State, within industry & 0.05 & $* * *$ & 0.02 & *** & 0.02 & *** & 0.04 & $* * *$ \\
\hline Non-neighbouring State, within industry & 0.09 & $* * *$ & 0.03 & $\star * *$ & 0.04 & *** & 0.07 & *** \\
\hline Within State, between industries & 0.06 & $* * *$ & 0.02 & *** & 0.01 & *** & -0.02 & *** \\
\hline Neighbouring State, between industries & 0.18 & $* * *$ & 0.05 & *** & 0.04 & *** & 0.06 & *** \\
\hline Non-neighbouring State, between industries & 0.19 & $* * *$ & 0.05 & $\star * *$ & 0.04 & *** & 0.06 & *** \\
\hline Distance between origin and destination States & -0.07 & $\star * \star$ & 0.00 & ** & 0.00 & & -0.02 & $* * *$ \\
\hline Distance squared & 0.01 & $* * *$ & 0.00 & & 0.00 & ** & 0.00 & *** \\
\hline \multicolumn{9}{|l|}{ Unemployment rates } \\
\hline Destination State, quarter $t$ & -0.02 & $* * *$ & -0.01 & $\star \star *$ & -0.01 & $\star \star \star *$ & -0.01 & *** \\
\hline Destination State, quarter $\mathrm{t}-1$ & 0.00 & * & 0.00 & ** & 0.00 & & 0.00 & * \\
\hline Origin State, quarter $\mathrm{t}$ & -0.02 & $* * *$ & -0.01 & *** & -0.01 & *** & -0.01 & *** \\
\hline Origin State, quarter $\mathrm{t}-1$ & 0.04 & $* * *$ & 0.02 & $* \star *$ & 0.02 & *** & 0.02 & *** \\
\hline Female & -0.02 & $* * *$ & -0.02 & $* * *$ & 0.01 & $\star * *$ & 0.01 & $* * *$ \\
\hline Age $14-18$ & 0.14 & $* * *$ & & & & & & \\
\hline Age $19-21$ & 0.02 & $* * *$ & & & & & & \\
\hline Age $45-54$ & & & & & -0.03 & $\star * *$ & & \\
\hline Age $65+$ & & & & & & & 0.04 & $* * *$ \\
\hline Constant & 0.06 & $* * *$ & 0.03 & $\star * *$ & -0.02 & $\star * *$ & -0.06 & $* * *$ \\
\hline \multicolumn{9}{|l|}{ Fixed effects } \\
\hline Destination State & $x$ & & $x$ & & $x$ & & $x$ & \\
\hline Origin State & $x$ & & $x$ & & $x$ & & $x$ & \\
\hline Destination industry & $x$ & & $x$ & & $x$ & & $x$ & \\
\hline Origin industry & $x$ & & $x$ & & $x$ & & $x$ & \\
\hline Year-quarter & $x$ & & $x$ & & $x$ & & $x$ & \\
\hline Observations & $7,718,170$ & & $7,549,996$ & & $10,709,229$ & & $4,838,363$ & \\
\hline Variables & 221 & & 219 & & 220 & & 220 & \\
\hline Clusters & 449,038 & & 552,698 & & 552,805 & & 363,331 & \\
\hline$R^{2}$ & 0.23 & & 0.16 & & 0.10 & & 0.08 & \\
\hline
\end{tabular}

Note: Earnings gain estimated relative to job-to-job move within State and within industry (excluded category). All job-to-job moves (with and without brief nonemployment are included). Log difference between average earnings before (t-1) and after ( $t+1$ or $t+2)$ job move. Earnings are deflated by the PCE deflator. Monthly State unemployment rates are sourced from BLS and averaged by quarter.

Source: OECD calculations based on Job-to-Job Flows database, Census Bureau.

39. The time-variation of interstate returns is analysed in a second set of regressions (Figure 17). To simplify, the regressions only include an indicator for interstate job-to-job move (both to neighbouring and non-neighbouring States) and an indicator for industry change. They are both interacted with year indicators to capture changes over time. The results point to an increasing return to interstate job-to-job moves for youth (age 14-24) and seniors (age 55+). The return to prime age displays only moderate variation during 2001-2017. Cyclical changes around the global financial crisis are only visible for young workers. Older age groups experienced clear drops in the return to industry change in 2009 , likely reflecting reduced employment options following the large increase in unemployment. 
Figure 17. The interstate job-to-job earnings return has increased for youth and seniors

Estimated earnings gain for interstate and industry change job-to-job moves, 2000 Q4-2018Q1

A. Age 14-24

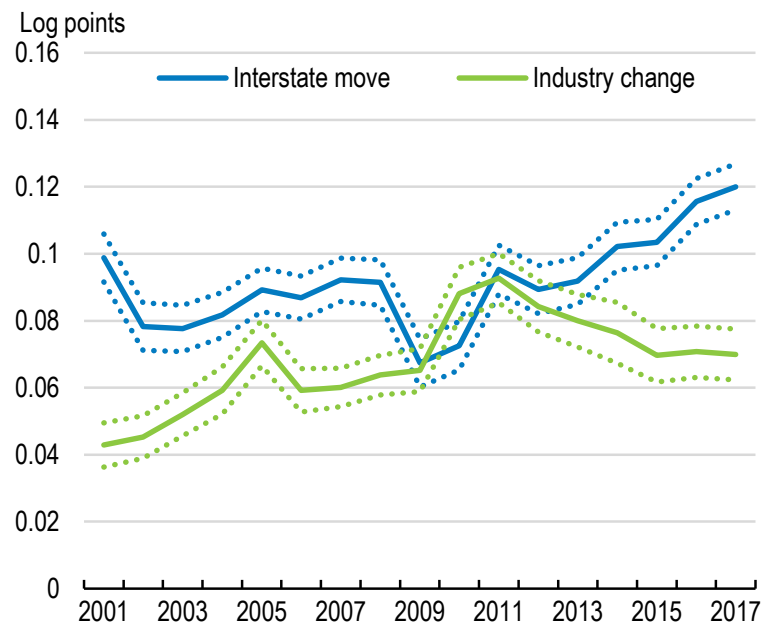

C. Age 35-54
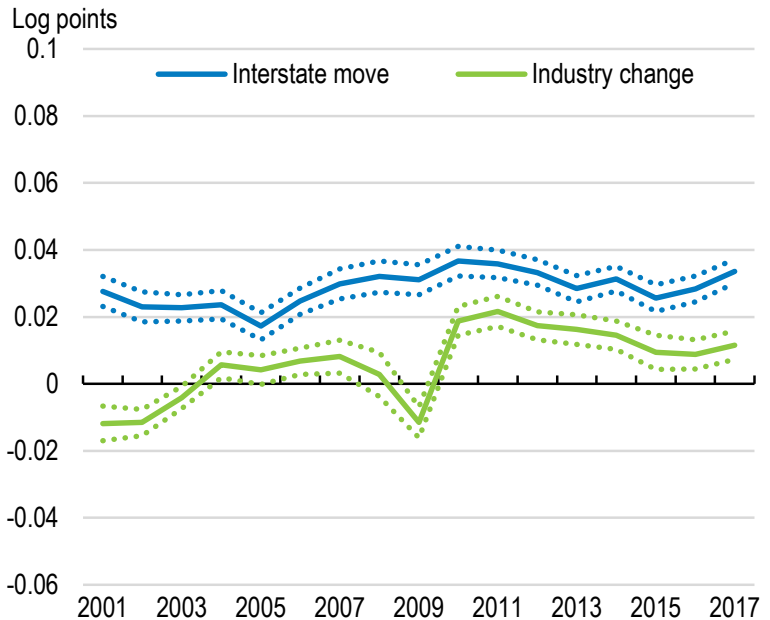

B. Age 25-34

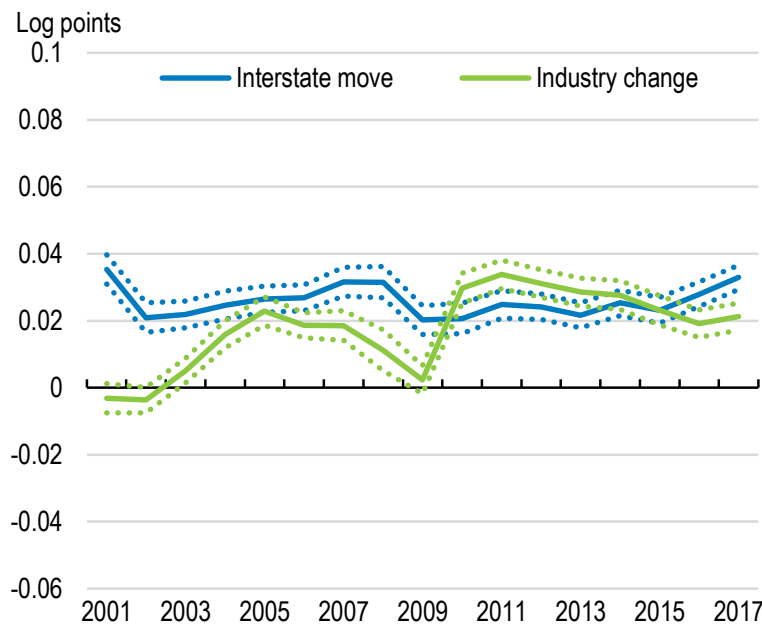

\section{Age 55+}

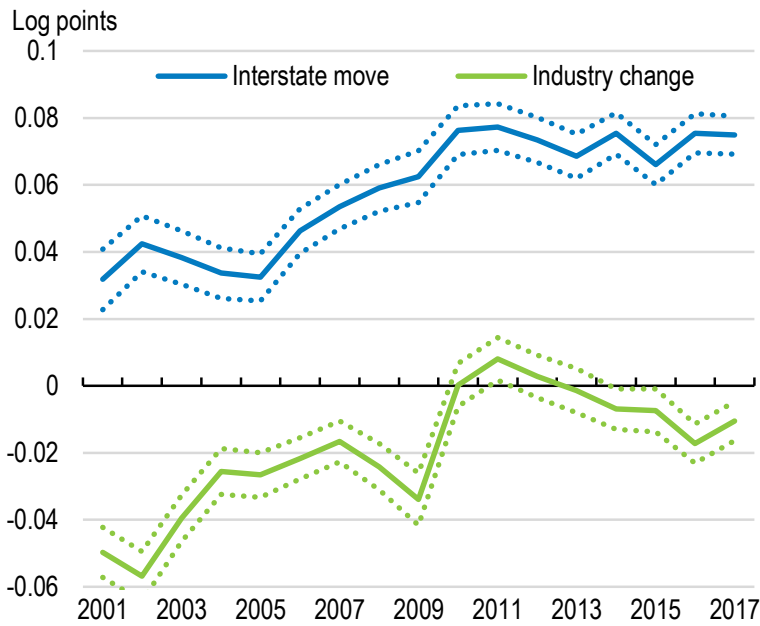

Note: The estimated models are similar to those in Table 5, with the indicator for interstate move including all job-to-job moves between States and industry change including both within and between State job-to-job moves. The charts show the estimate for the two indicators interacted with annual time controls.

Source: OECD calculations based on Job-to-Job Flows database, Census Bureau.

40. Future work could explore these tentative findings further as data availability becomes better and more granular. For example, why has interstate job-to-job mobility displayed such apparent stability over time, while overall job mobility and interstate migration has trended downwards? Has the (causal) return to interstate job mobility increased for some age groups and if so which factors may be holding people back from relocating? 


\section{The influence of demographic changes on job mobility}

41. The United States is currently facing rapid ageing due to baby-boomers reaching retirement ages. This is visible by a sizeable increase in the dependency ratio by almost 7 percentage points from 2010 to 2020 (Figure 18). While the United States remains a younger nation than Japan and Europe, the slope of the dependency ratio is the crucial matter for the present analysis. The curve is currently at its steepest part observed since the 1980 s and steeper than in any years projected until 2070 . By this measure, the strongest headwind from ageing to the labour market may thus be concentrated over the latest and the coming decade. This matters for job mobility through more exits to retirement and by compositional changes of the working-age population, with a rising share of less mobile senior workers and a declining share of more mobile youth.

\section{Figure 18. Ageing is accelerating in the United States but remains below other countries}

Population above age 65 in per cent of population aged 20-64

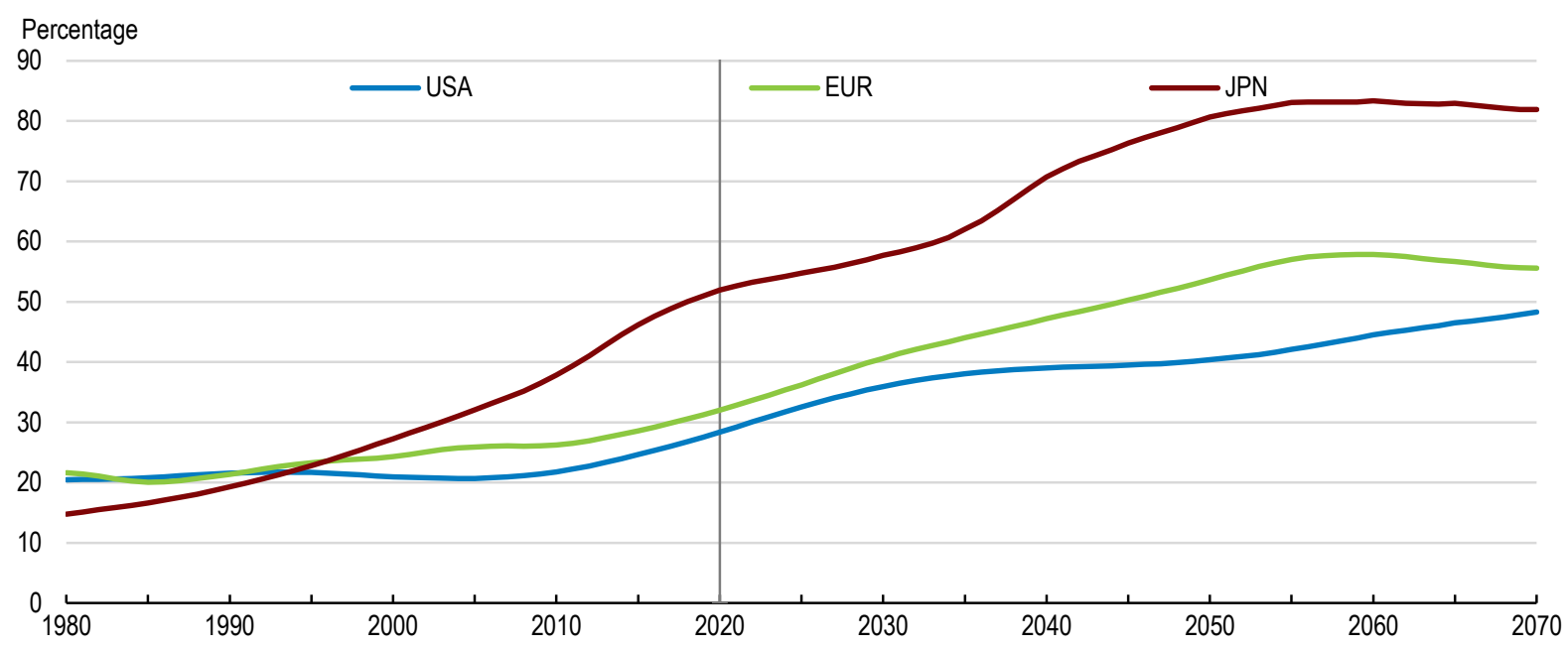

Note: Europe (EUR) includes the countries as defined by the World Population Prospects.

Source: United Nations, World Population Prospects: The 2019 Revision.

\section{Ageing has reduced labour market participation}

42. A simple shift-share exercise suggests that ageing can explain a sizeable part of the decline in the overall labour force participation rate (age 15+) from 2000 to 2018 (Figure 19, Panel A). The participation rate has declined by almost 6 percentage points for men and by 3 percentage points for women. In a counterfactual scenario with fixed (five-year) age group population shares, i.e. only accounting for changing participation within narrow age groups, the decline is less than half for men and almost eliminated for women. However, demographic changes is only one among various factors (Abraham and Kearney, 2020) and cannot explain the decline in participation for the prime age population (Figure 19, Panel B), which is raising concern and has been related to the opioid crisis among other factors (OECD, 2018b). 


\section{Figure 19. Ageing is an important factor for the labour force participation decline}

\section{Labour force participation rates}

A. Total population (age $15+$ )
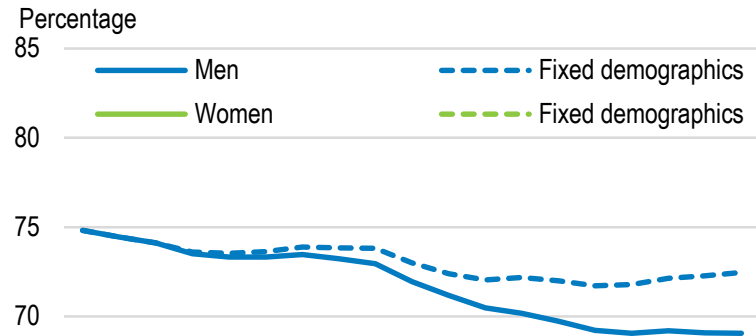

65

60

55

$2000 \quad 2002 \quad 2004 \quad 2006 \quad 20082010 \quad 2012 \quad 2014 \quad 2016 \quad 2018$
B. Prime age population (age 25-54)

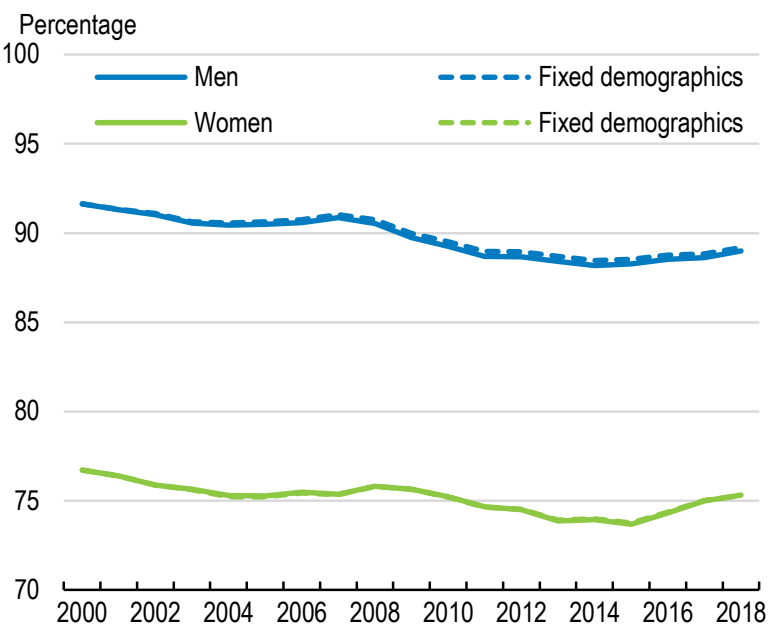

Note: Fixed demographics refer to a counterfactual participation rate constructed by fixing five-year age population group shares at their levels in 2000 and using observed participation rates within age groups.

Source: OECD calculations based on OECD Labour Force Statistics.

43. The United States, along with some Nordic countries, stands out as one of the few OECD countries to experience a sizeable decline in labour force participation from 2000 to 2018 (Figure 20). Although participation for the working-age population (age 20-64) started at a high level, it now sits in the bottom half of OECD countries (Panel A). A similar shift-share calculation as above suggests that the United States has indeed experienced one of the strongest downward effects of demographic changes on participation along with Poland, France and Canada (Panel B). Nonetheless, the vast majority of OECD countries experienced increasing participation despite the headwind from ageing. Some of the identified factors are specific to the United States and partly accounts for these differences such as the large shock from increased import competition from China and the high incarceration rate (Abraham and Kearney, 2020). Policy factors are also likely to matter such as the weak support to job seekers through active labour market programmes and accessing affordable childcare and care for the elderly (OECD, 2018b). Moreover, the availability of disability insurance as an income substitute may have induced workers with long unemployment spells to move out of the labour force (Bown and Freund, 2019). 
Figure 20. The decline in participation since 2000 is the largest across OECD countries

A. Labour force participation (age 20-64)

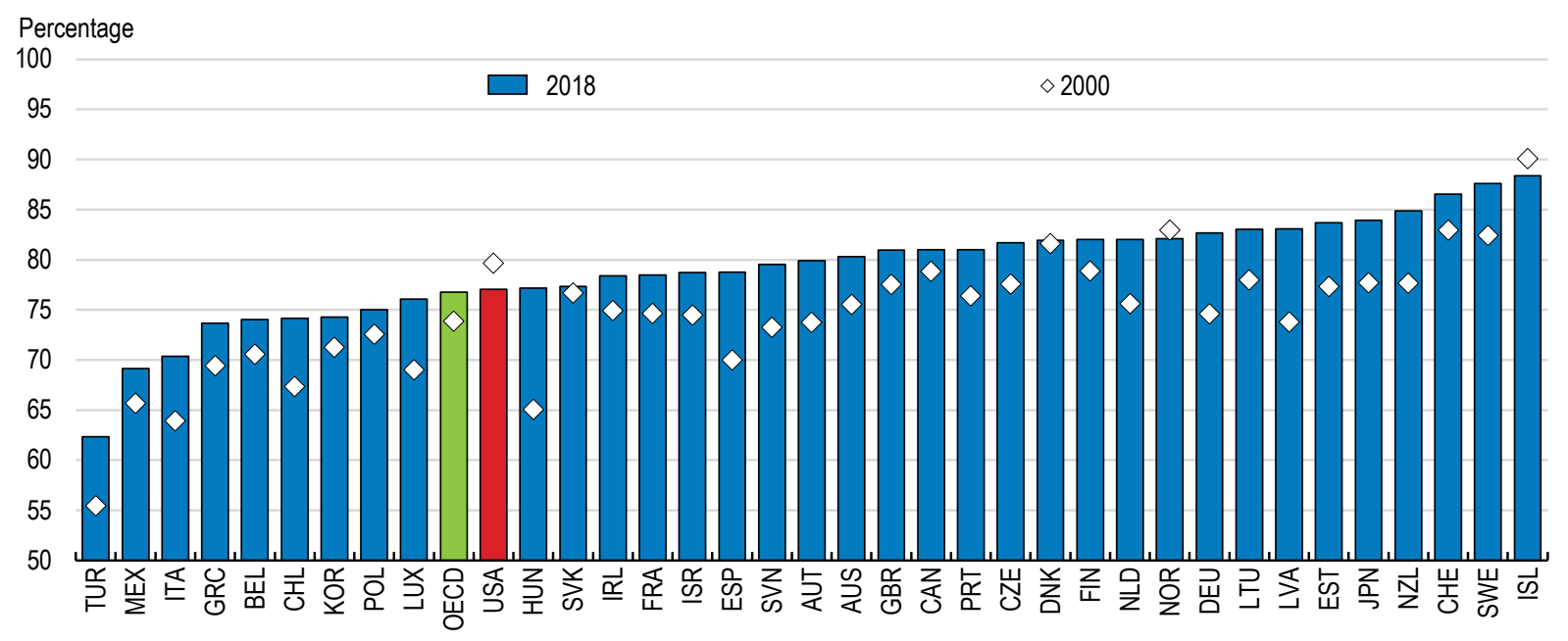

B. Change in labour force participation (age 20-64) explained by demographic changes, 2000-2018

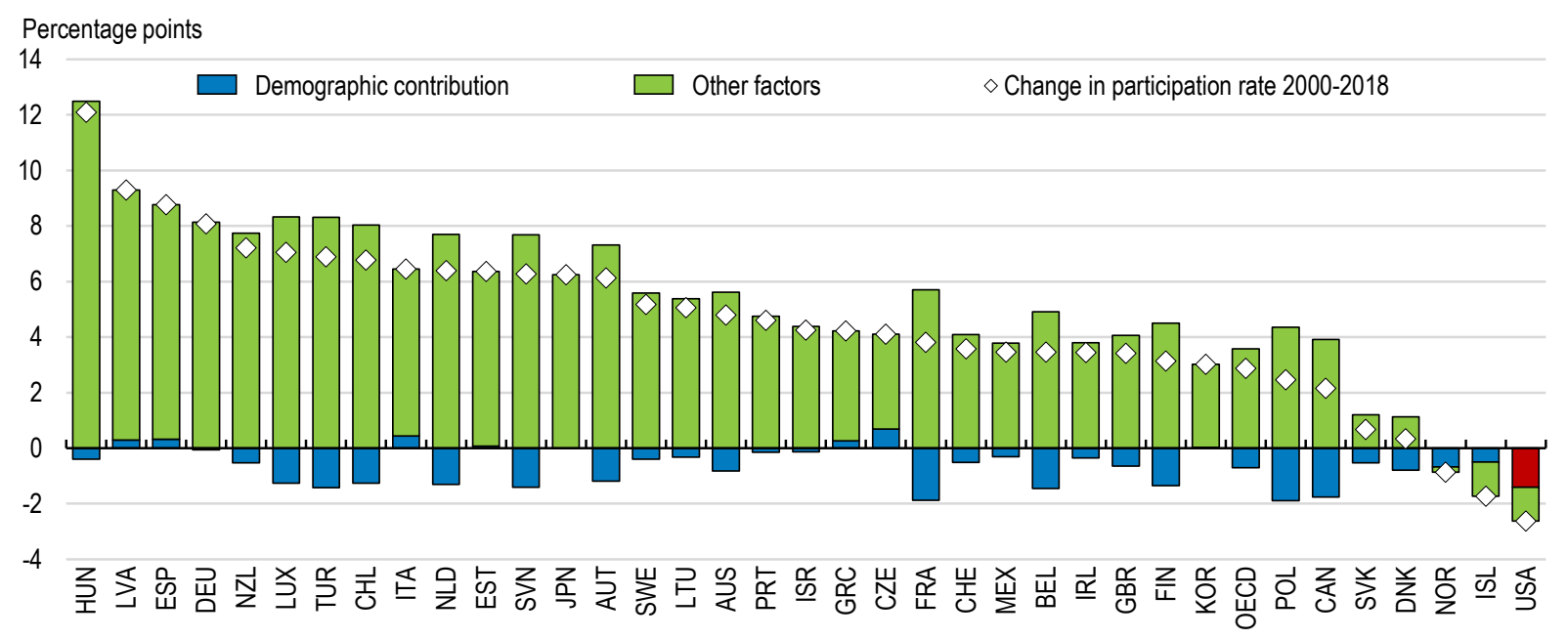

Note: The demographic contribution is the difference between the observed labour force participation and a counterfactual with fixed population shares, cf. Figure 19.

Source: OECD calculations based on OECD Labour Force Statistics.

\section{Ageing of the working-age population has reduced job mobility}

44. Compositional changes of the working-age population can explain a sizeable part of the decline in job hire and separation rates (Figure 1, Panel D). The share of seniors age 55 and above in total employment has risen from less than $13 \%$ to $23 \%$ from 2000 to 2018 (Figure 21, Panel B). Since seniors tend to make many fewer job transitions compared to youth and prime age workers (Figure 3 ), ageing of the workforce has pushed down labour mobility measures (Figure 22, Panel A; see Figure A.8 in the Annex for job-to-job and nonemployment hire rates). The shift-share calculation suggests that the job hire rate would have been 1.2 percentage points higher in 2018 if the age group composition had remained as in 2000. Demographic changes thus account for around half of the decline in the job hire rate since 2000, according to this simple calculation. This is consistent with analyses based on the survey data taking a 
longer time perspective and finding that demographics can explain around half of declining labour market fluidity (Molley et al., 2016; Gittleman, 2019).

45. The employment composition with respect to race and ethnicity has also changed, which by contrast has tended to increase job hire and separation rates slightly (Figure 22, Panel B). The reason is that Hispanic or Latino and Black workers compose a larger share of employment (Figure 21, Panel C) and they have higher job hire rates compared to whites alone (Figure 5). However, a rising share of Asians mitigates the impact, as Asians have the lowest average job-hire rate across all groups. Overall, the effect of changing race and ethnicity composition is small, around 0.3 percentage point increase in the job hire rate.

46. Lastly, a tentative shift-share calculation for firm age (destination for job hire) suggests that fewer young firms contributes to the decline in the job hire rate by around 0.6 percentage points, corresponding to about a quarter of the decline since 2000 (Figure 22, Panel C). The changing firm-age distribution reflects the declining trend in business dynamics (Decker et al., 2016), which contributes to reduce labour mobility from the demand side. However, for that reason the result also suffers from endogeneity issues since starting a business, expanding or closing it are choices influenced by the current economic environment as well as factors like the age distribution of the labour force. There is thus a risk of double counting and the quantified effect of changing firm-age distribution should be interpreted with caution. Endogeneity is much less of an issue for the age, race and ethnicity employment distributions since birth rates years ago are their main determinant. 
Figure 21. Employment composition has changed, notably on worker age, race and firm age

Percentage of employment

\section{A. Gender}

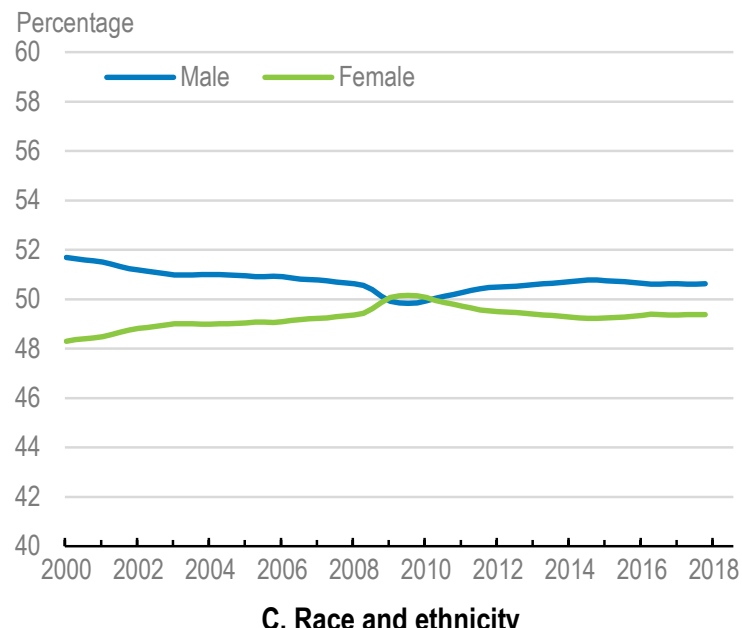

C. Race and ethnicity

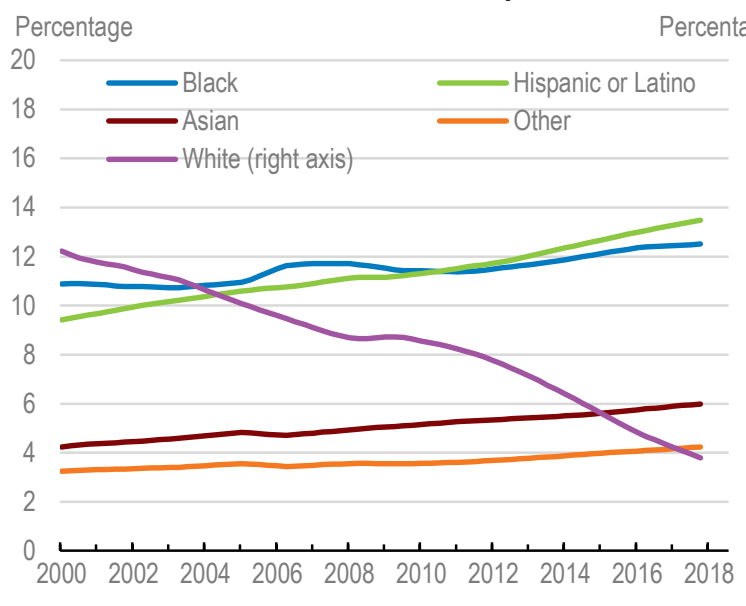

E. Firm age

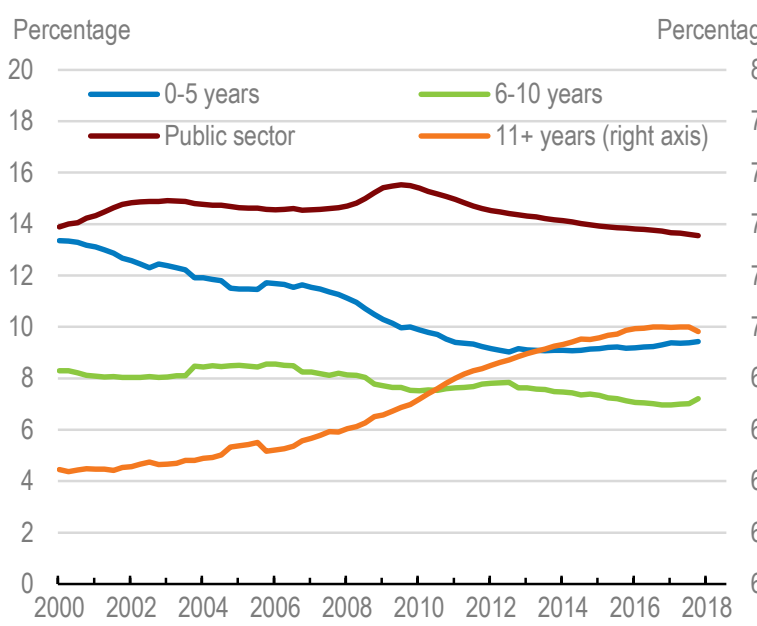

B. Age
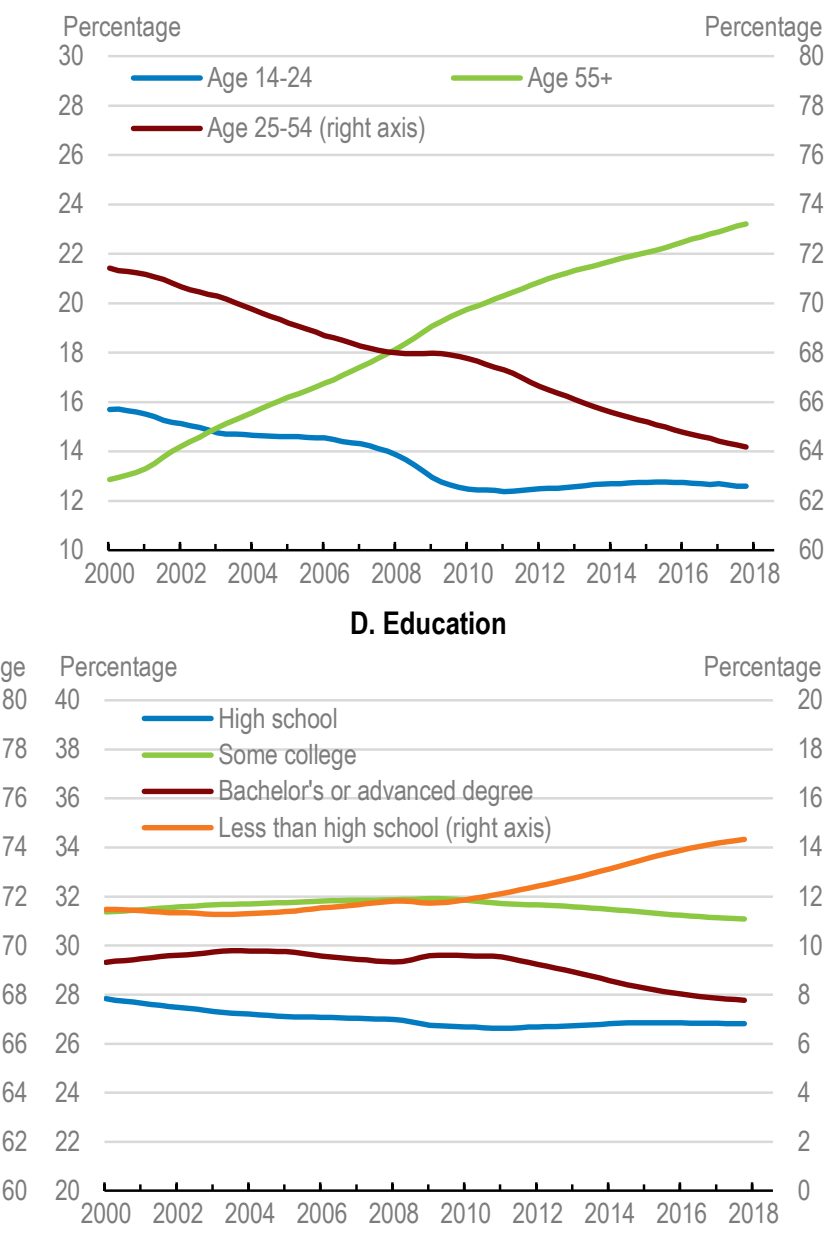

\section{F. Firm size}

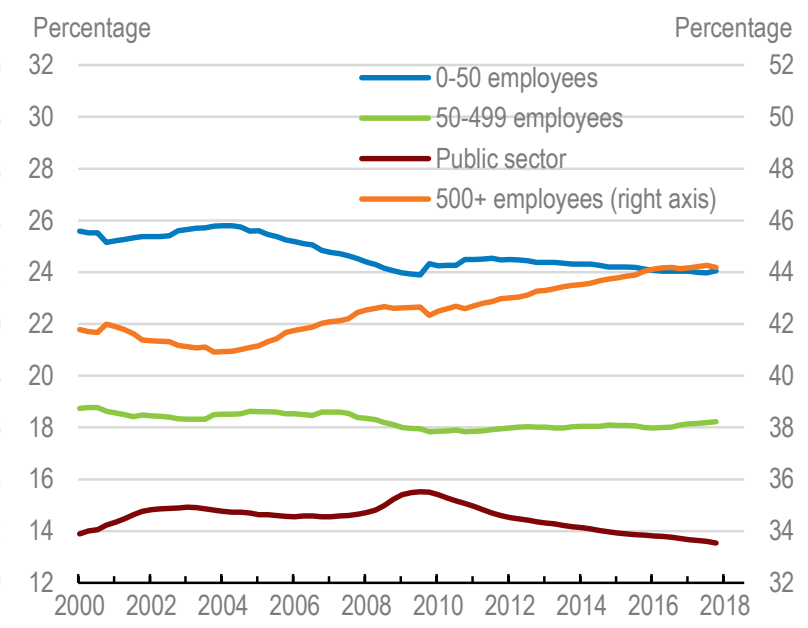

Source: OECD calculations based on Job-to-Job Flows database, Census Bureau. 
Figure 22. Ageing has reduced the job hire rate substantially
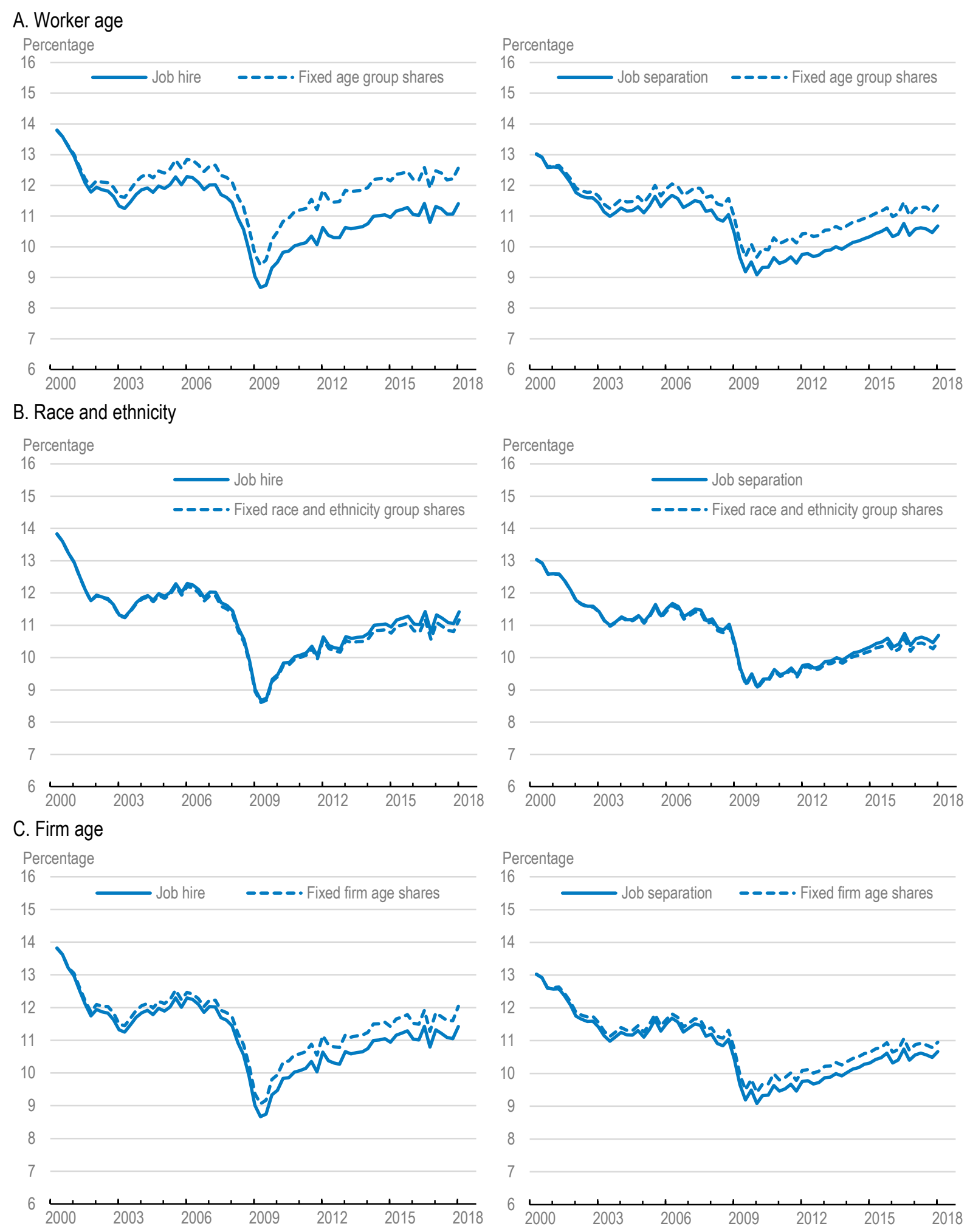

Note: Solid lines show the observed job hire and job separation rates. Dashed lines show counterfactuals with compositional shares fixed at their 2000 levels (the calculation applies more groups than shown in Figure 21) and only accounting for within group changes.

Source: OECD calculations based on Job-to-Job Flows database, Census Bureau. 


\section{Concluding remarks}

47. Job-to-job flows is a key channel for workers to make career progress and to increase their earnings. As shown by the results, job-to-job hires account for almost half of all hires and display much more cyclical variation than hires from nonemployment. However, the U.S. population has become less mobile over time: the share of the population moving each year has fallen from around $20 \%$ in the 1970 s to under $10 \%$ more recently, with moves across States and moves to look for work also having been reduced. This paper has examined the patterns of job mobility by looking not only at the spatial dimension of mobility but also by examining the heterogeneity in mobility across a number of individual and firm level characteristics during 2000-2018.

48. Three interesting findings emerge. First, the decline in job mobility over time is driven mainly by hires from nonemployment, while the job-to-job hire rate prior to the COVID-19 crisis had recovered to its previous high in the mid-2000s. While ageing and senior workers' increasing participation explain part of the declining nonemployment hire, evidence is emerging that getting onto the job ladder has become more difficult. Second, the typical disadvantaged groups (youth, non-whites, less educated) have the highest job mobility rates and the observed job-to-job movers experience the highest associated earnings gain. Together, these findings point to the large benefits of a dynamic labour market and an effective job ladder, but this needs to be balanced against the potential role of precarious work and that the analysis is descriptive. Third, the new J2J data reveal many interesting patterns of job moves across State borders, with a remarkable stability in the aggregate interstate job-to-job hire over the last two decades.

43. Although this paper has attempted to underline the key differences in labour market fluidity across States and other individual and firm characteristics, future research could further explore these tentative findings by relying on more granular data to establish causal inferences. As data availability becomes better, it would be interesting to examine why interstate job-to-job mobility displayed such an apparent stability over time, while overall job mobility and interstate migration has trended downwards. Has the causal return to interstate job mobility increased for some age groups and other individual characteristics and if so which factors may be holding people back from relocating?

\section{References}

Abraham, K.G. and M.S. Kearney (2020), "Explaining the Decline in the US Employment-to-Population Ratio: A Review of the Evidence", Journal of Economic Literature, Vol. 58/3, pp. 585-643.

Autor, D. (2019), "Work of the Past, Work of the Future", AEA Papers and Proceedings, Vol. 109, pp. 132.

Azzopardi, D., F. Fareed. P. Lenain and D. Sutherland (2020), "Why Are Some US Cities Successful, While Others Are Not? New Evidence from Machine Learning", OECD Economics Department Working Papers, OECD Publishing, Paris, forthcoming.

Bambalaite, I., G. Nicoletti and C. von Rueden (2020), "Occupational Entry Regulations and their Effects on Productivity in Services: Firm-Level Evidence", OECD Economics Department Working Papers, No. 1605, OECD Publishing, Paris, https://doi.org/10.1787/c8b88d8b-en.

Barrero, J. M., N. Bloom and S.J. Davis (2020), "COVID-19 Is Also a Reallocation Shock”, NBER Working Paper, No. 27137.

Barth, E., J. Davis and R.B. Freeman (2018), "Augmenting the Human Capital Earnings Equation with Measures of Where People Work", Journal of Labor Economics, Vol. 36/S1, S71-S97.

Bown, C. and C. Freund (2019), "The Problem of US Labor Force Participation", Peterson Institute for International Economics Working Paper, No. 19-1. 
Cadena, B.C. and B.K. Kovak (2016), "Immigrants Equilibrate Local Labor Markets: Evidence from the Great Recession", American Economic Journal: Applied Economics, Vol. 8/1, pp. 257-290.

Decker, R., J. Haltiwanger, R. Jarmin and J. Miranda (2016), "Declining Business Dynamism: What We Know and the Way Forward", American Economic Review: Papers \& Proceedings, Vol. 106/5, pp. 203207.

Decker, R., J. Haltiwanger, R. Jarmin and J. Miranda (2017), "Declining Dynamism, Allocative Efficiency, and the Productivity Slowdown", American Economic Review: Papers \& Proceedings, Vol. 107/5, pp. 322326.

Fallick, B. and C. Fleischman (2004), "Employer-to-Employer Flows in the U.S. Labor Market: The Complete Picture of Gross Worker Flows", FEDS Working Papers, No. 2004-34.

Foster, L., C. Grim and J. Haltiwanger (2016), "Reallocation in the Great Recession: Cleansing or Not?", Journal of Labor Economics, Vol. 34/S1, pp. S293-S331.

Garnero, A., A. Hijzen and S. Martin (2019), "More Unequal, but More Mobile? Earnings Inequality and Mobility in OECD Countries", Labour Economics, Vol. 56, pp. 26-35.

Gittleman, M. (2019), "Declining Labor Turnover in the United States: Evidence and Implications from the Panel Study of Income Dynamics", Monthly Labor Review, U.S. Bureau of Labor Statistics, January.

Haltiwanger, J., H. Hyatt, E. McEntarfer (2018), "Who Moves Up the Job Ladder?", Journal of Labor Economics, Vol. 36/S1, pp. S301-S336.

Haltiwanger, J. and J.R. Spletzer (2020), "Rising Between Firm Inequality and Declining Labor Market Fluidity: Evidence of a Changing Job Ladder", in: Chette, R. et al. (eds.), Measuring and Understanding the Distribution and Intra/Inter-Generational Mobility of Income and Wealth, National Bureau of Economic Research.

Hermansen, M. (2020), "Anti-competitive and Regulatory Barriers in the United States Labour Market", OECD Economics Department Working Papers, No. 1627, OECD Publishing, Paris, https://doi.org/10.1787/38649656-en.

Hermansen, M. (2019), "Occupational Licensing and Job Mobility in the United States", OECD Economics Department Working Papers, No. 1585, OECD Publishing, Paris, https://doi.org/10.1787/4cc19056-en.

Hyatt, H. et al. (2017), “Job-to-Job Flows: New Statistics on Worker Reallocation and Job Turnover”, U.S. Census Bureau.

Hyatt, H., E. McEntarfer, K. Ueda, A. Zhang (2018), "Interstate Migration and Employer-to-Employer Transitions in the United States: New Evidence from Administrative Records Data", Demography, Vol. 55/6, pp. 2161-2180.

Hyatt, H. and J. Spletzer (2013), "The Recent Decline in Employment Dynamics", IZA Journal of Labor Economics, Vol. 2/5, pp.

Kambourov, G. and I. Manovskii (2008), "Rising Occupational and Industry Mobility in the United States: 1968-97", International Economic Review, Vol. 49/1, pp. 41-79.

Molloy, R., R. Trezzi, C.L. Smith and A. Wozniak (2016), "Understanding Declining Fluidity in the U.S. Labor Market”, Brookings Papers on Economic Activity, Spring, pp. 183-237.

Molloy, R., C.L. Smith and A. Wozniak (2011), "Internal Migration in the United States", Journal of Economic Perspectives, Vol. 25/3, pp. 173-196.

OECD (2020), OECD Economic Surveys: United States 2020, OECD Publishing, Paris, https://doi.org/10.1787/12323be9-en. 
OECD (2018a), Good Jobs for All in a Changing World of Work: The OECD Jobs Strategy, OECD Publishing, Paris, https://doi.org/10.1787/9789264308817-en

OECD (2018b), OECD Economic Surveys: United States 2018, OECD Publishing, Paris, https://doi.org/10.1787/eco surveys-usa-2018-en.

Sutherland, D. (2020), "Modernising State-level Regulation and Policies to Boost Mobility in the United States", OECD Economics Department Working Papers, No. 1628. OECD Publishing, Paris, https://doi.org/10.1787/a06a959b-en. 


\section{Annex A. Supplementary figures and tables}

\section{Figures}

Figure A.1. Employment distribution across industries

Percentage of total employment, average 2000 Q2-2018 Q1

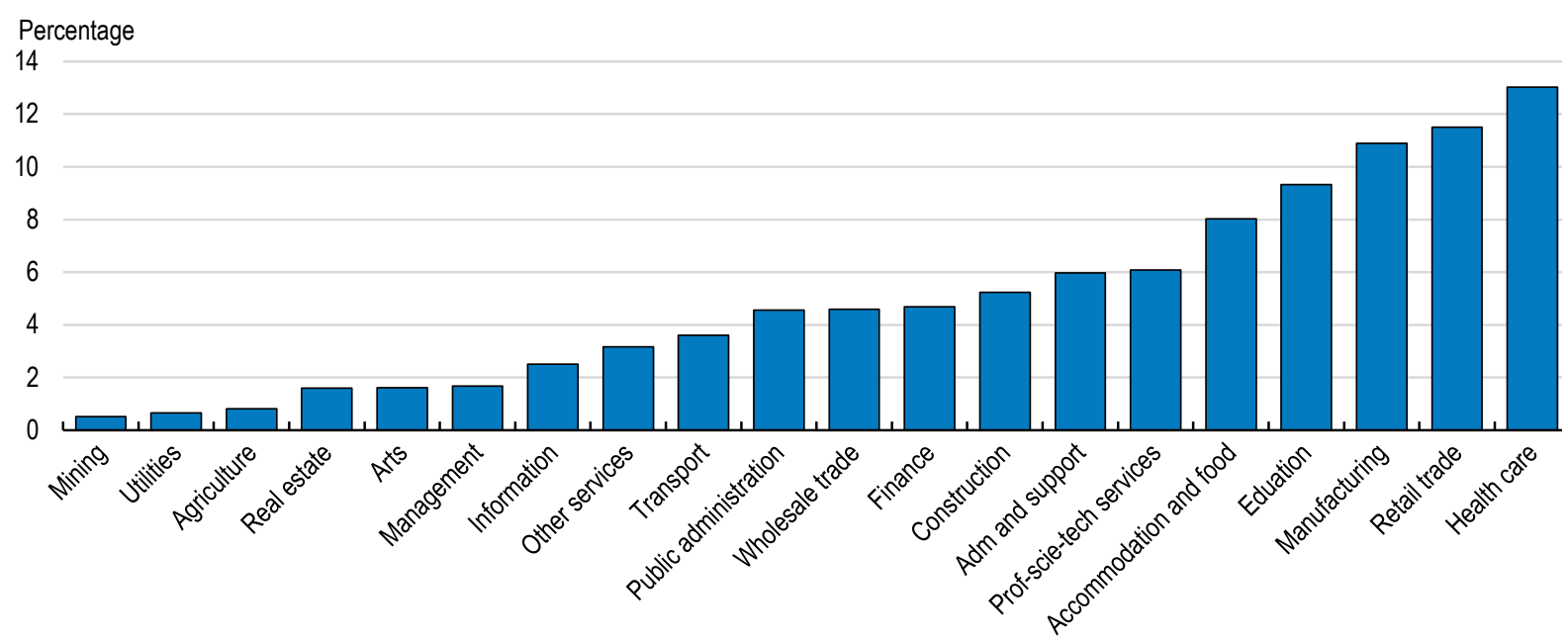

Note: Industries defined at the NAICS 2-digit level.

Source: OECD calculations based on Job-to-Job Flows database, Census Bureau.

Figure A.2. Employment distribution across divisions and regions

Percentage of total employment, average 2010 Q2-2016 Q1

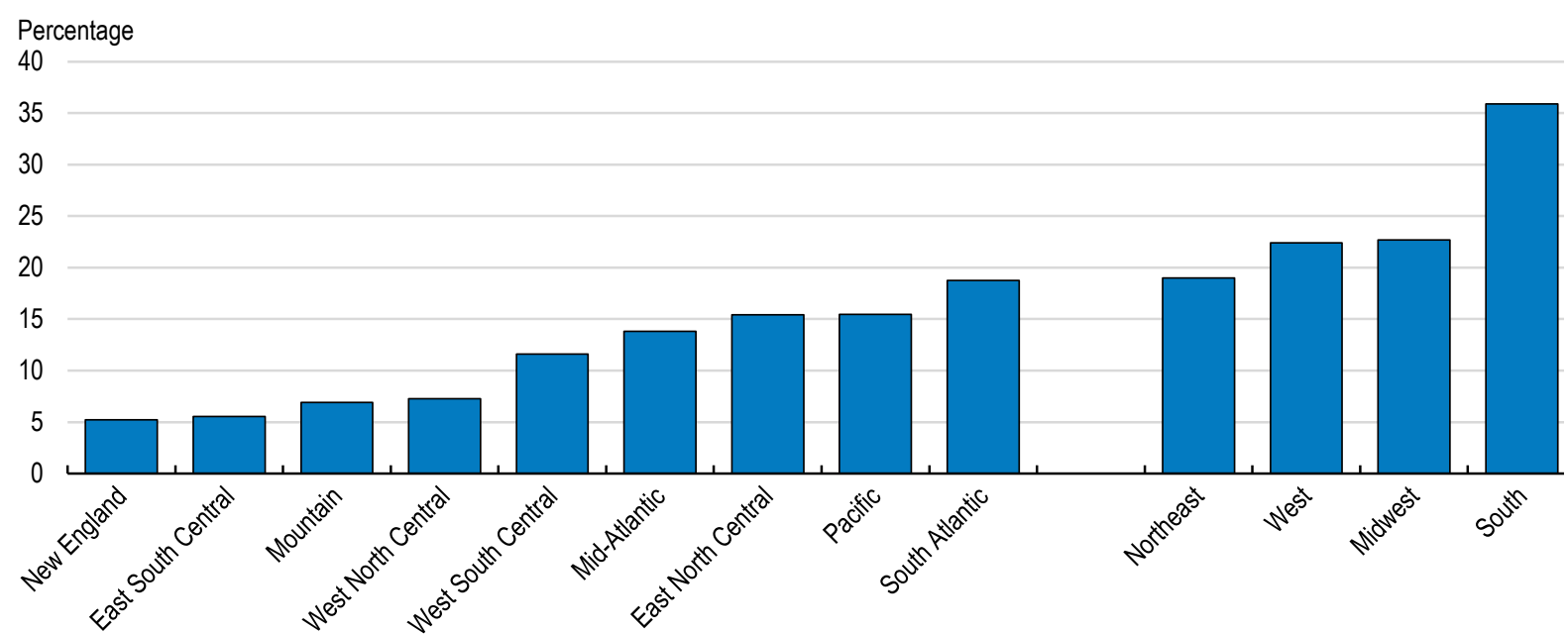

Source: OECD calculations based on Job-to-Job Flows database, Census Bureau. 
Figure A.3. Employment distribution across States

Percentage of total employment, average 2010 Q2-2016 Q1

\section{Percentage}

12

10

8

6

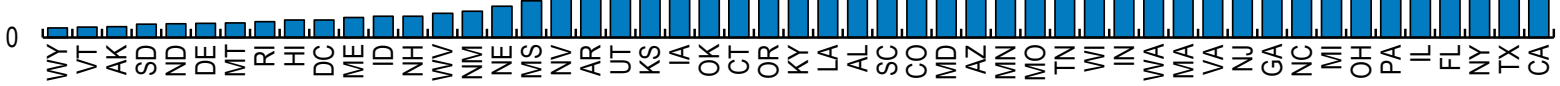

Source: OECD calculations based on Job-to-Job Flows database, Census Bureau.

Figure A.4. Job hire rates across States

Percentage of employment, average 2010 Q2-2016 Q1

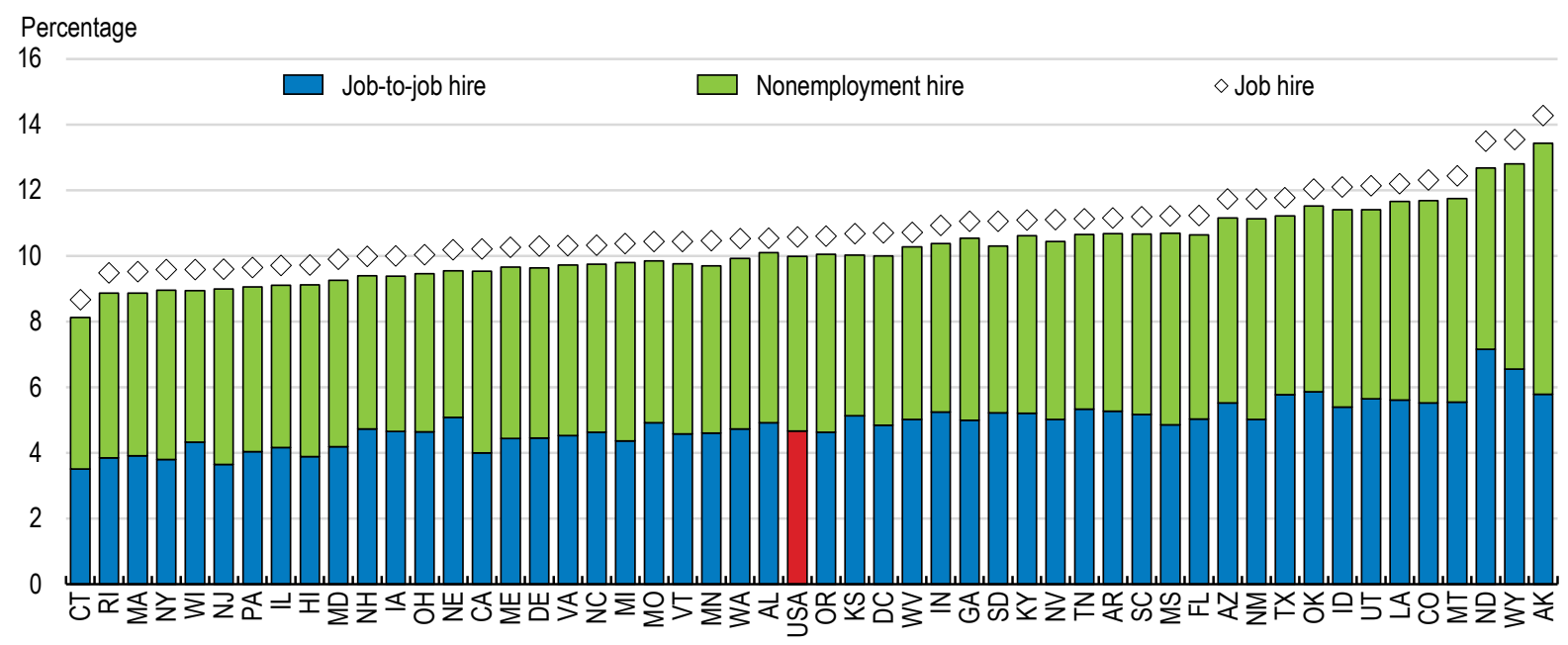

Source: OECD calculations based on Job-to-Job Flows database, Census Bureau. 
Figure A.5. Job mobility is lowest in the Northeast and highest in the South

Job hire rates across divisions and regions, average 2010 Q2-2016 Q1

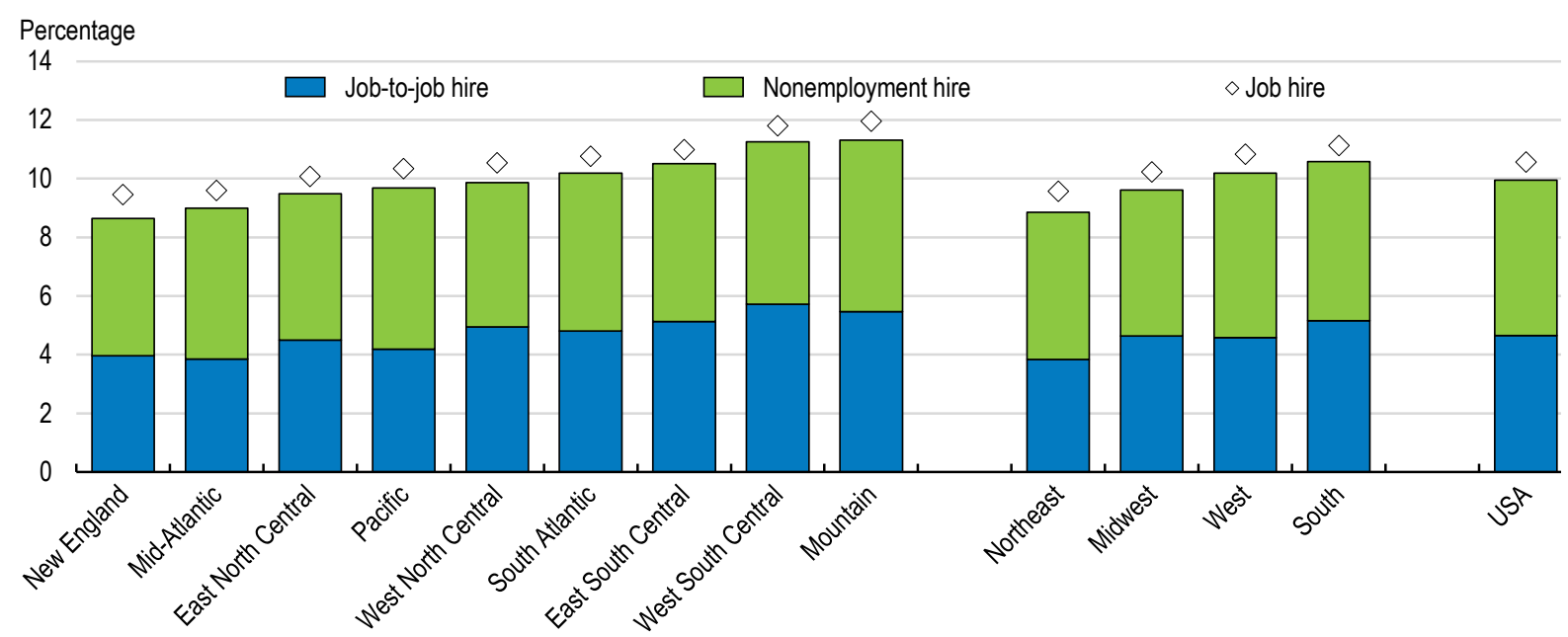

Note: The time period is the largest possible to include all States. The hire rate is the sum of job-to-job hire and nonemployment hire rate plus a small residual reflecting hire to a new main job, while maintaining a previous main job as a secondary job.

Source: OECD calculations based on Job-to-Job Flows database, Census Bureau.

Figure A.6. Robustness: job-to-job hire within and between States

Balanced sample of 34 States. Job-to-job hire by type of move, per cent of aggregate employment

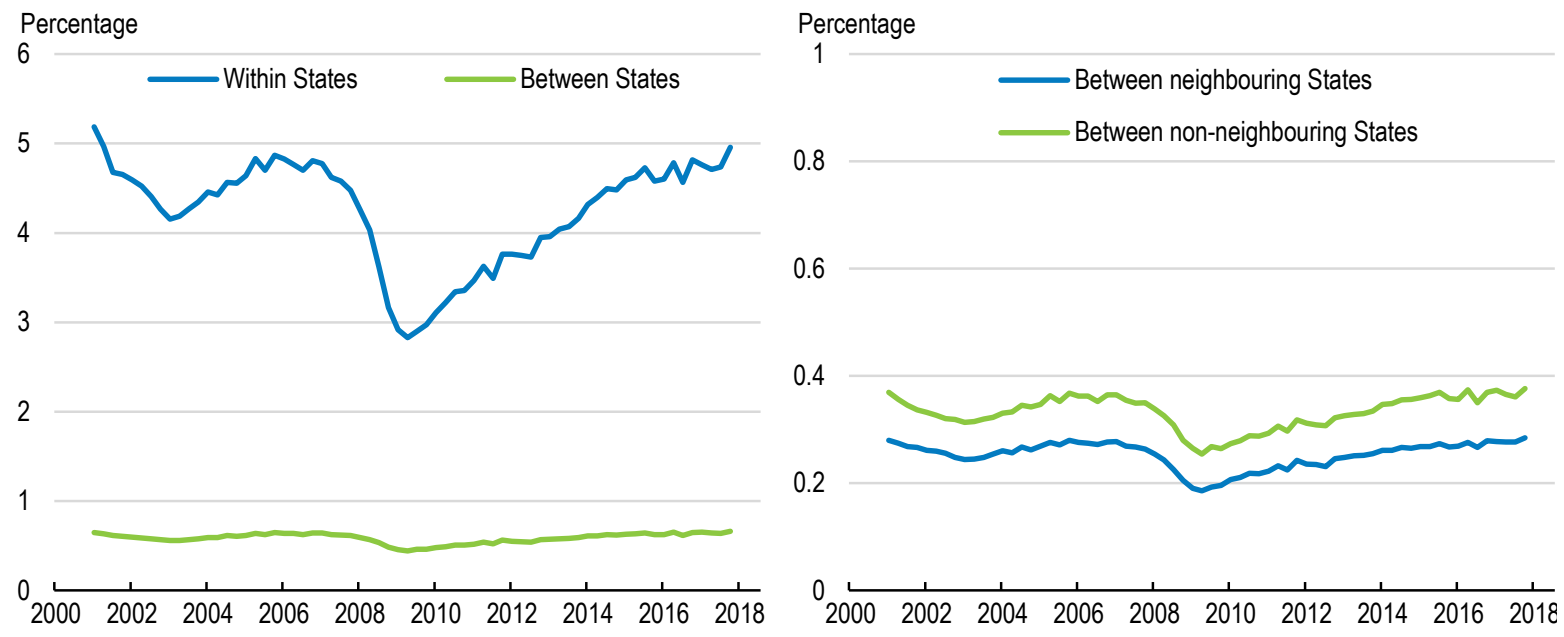

Note: All inflows and outflows from the 17 excluded States (AK, AR, AZ, CT, DC, LA, MA, MD, ME, MS, NH, NM, RI, SD, TN, VA, VT) are deleted to obtain a balanced sample.

Source: OECD calculations based on Job-to-Job Flows database, Census Bureau. 
Figure A.7. The interstate job-to-job earnings return has increased for low-skilled

Estimated earnings gain for interstate and industry change job-to-job moves, 2000 Q4-2018Q1

\section{A. Less than high school}
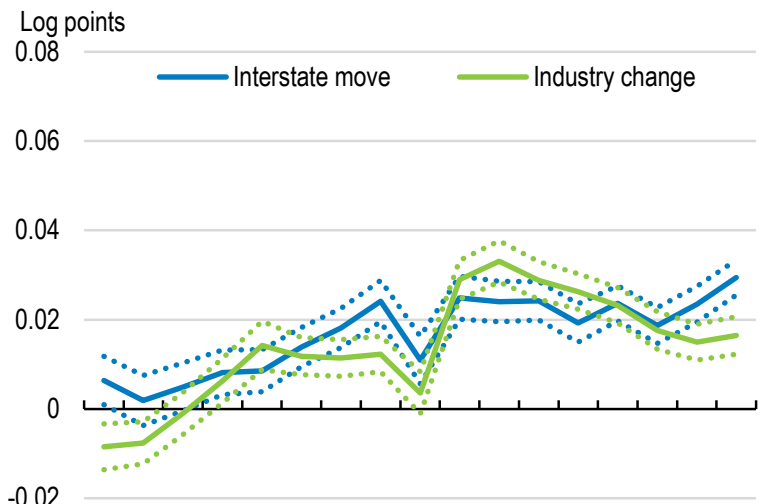

$-0.04$ $\begin{array}{lllllllll}2001 & 2003 & 2005 & 2007 & 2009 & 2011 & 2013 & 2015 & 2017\end{array}$

\section{Some college}
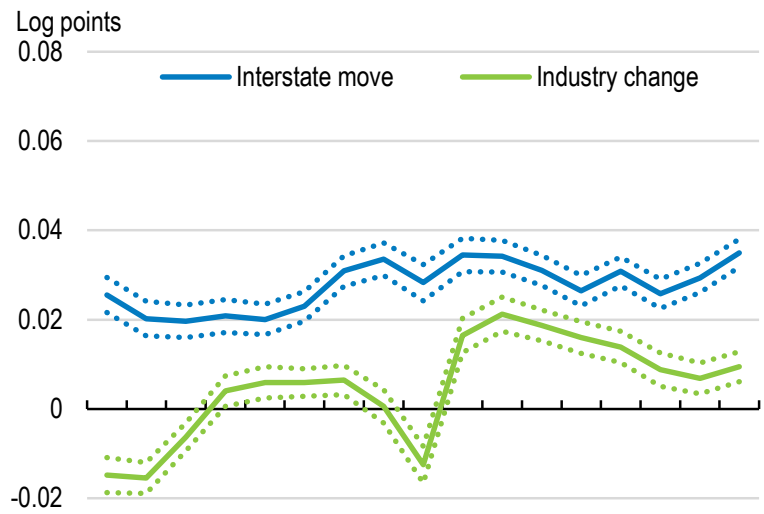

$-0.04$ $\begin{array}{lllllllll}2001 & 2003 & 2005 & 2007 & 2009 & 2011 & 2013 & 2015 & 2017\end{array}$
B. High school only

Log points
$0.08 \longrightarrow$ Interstate move $\quad$ Industry change

0.04

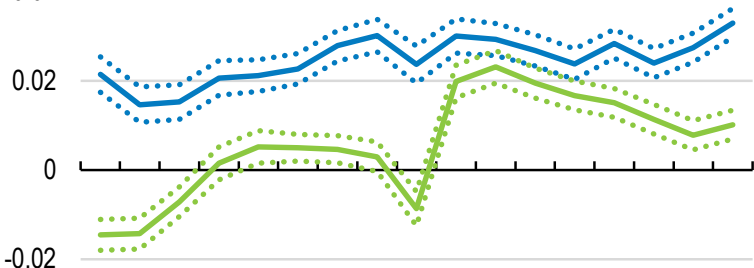

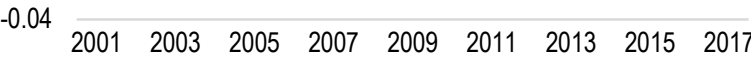

\section{Bachelor's or advanced degree}

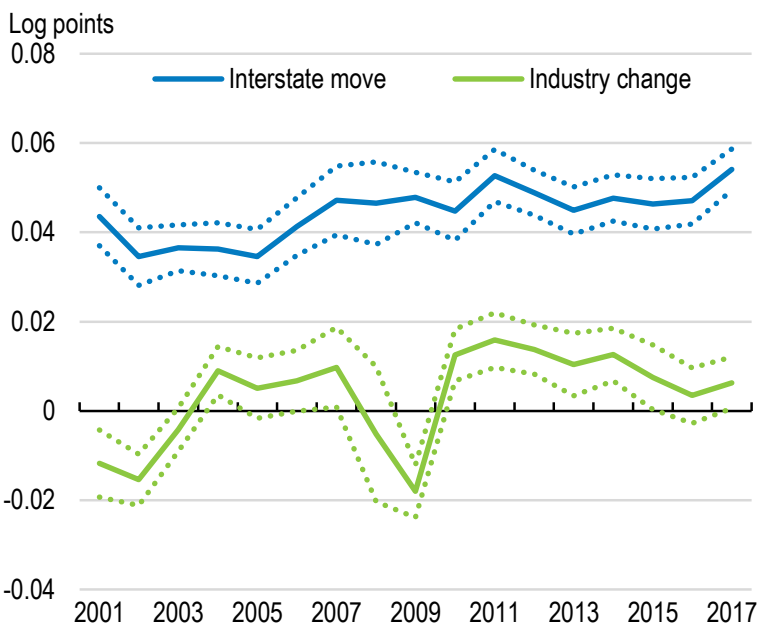

Note: The estimated models are similar to those in Table 5, with the indicator for interstate move including all job-to-job moves between States and industry change including both within and between State job-to-job moves. The charts show the estimate for the two indicators interacted with annual time controls.

Source: OECD calculations based on Job-to-Job Flows database, Census Bureau. 
44 | ECO/WKP(2020)52

Figure A.8. Changing demographics primarily affect the nonemployment hire rate

A. Worker age
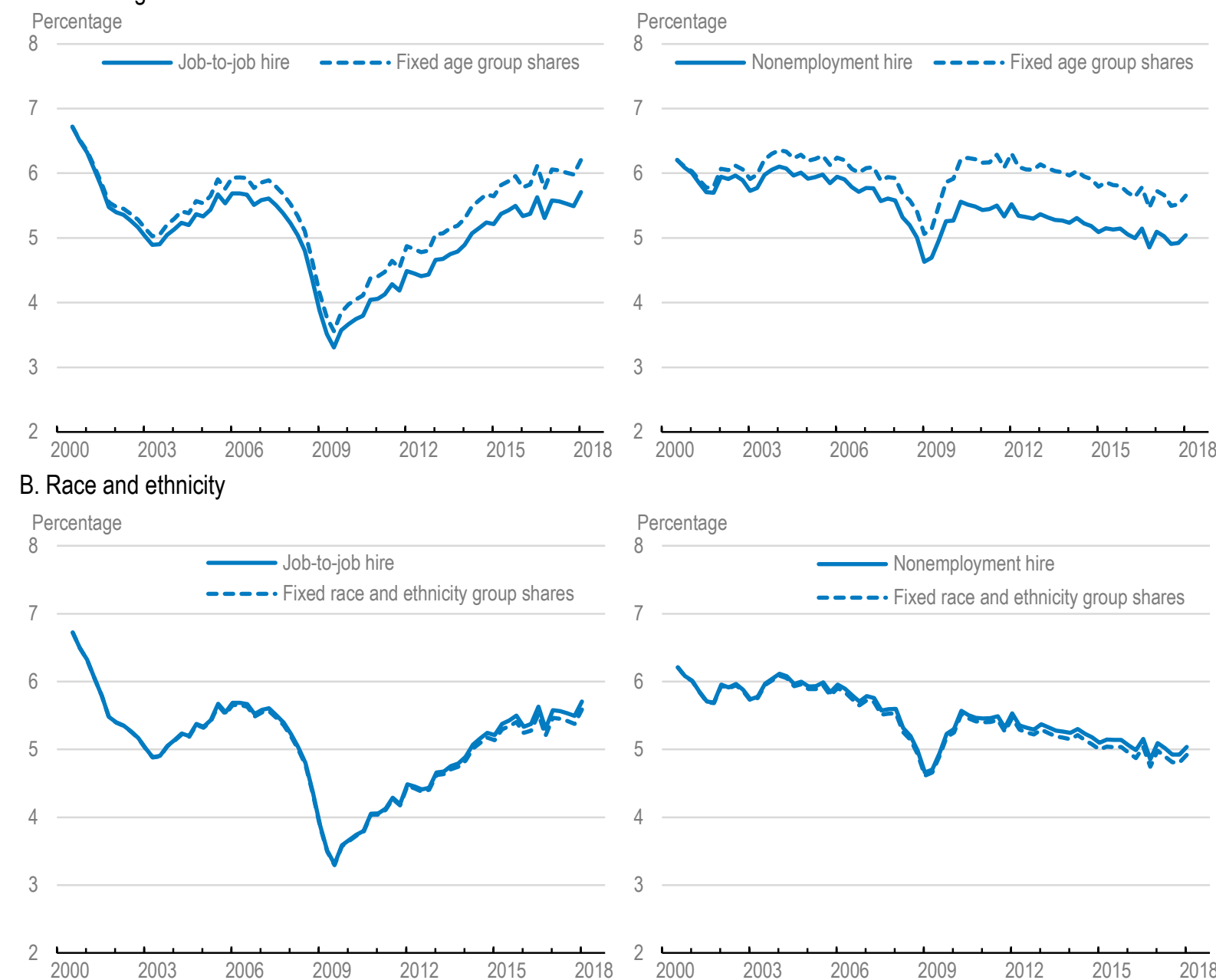

\section{Firm age}
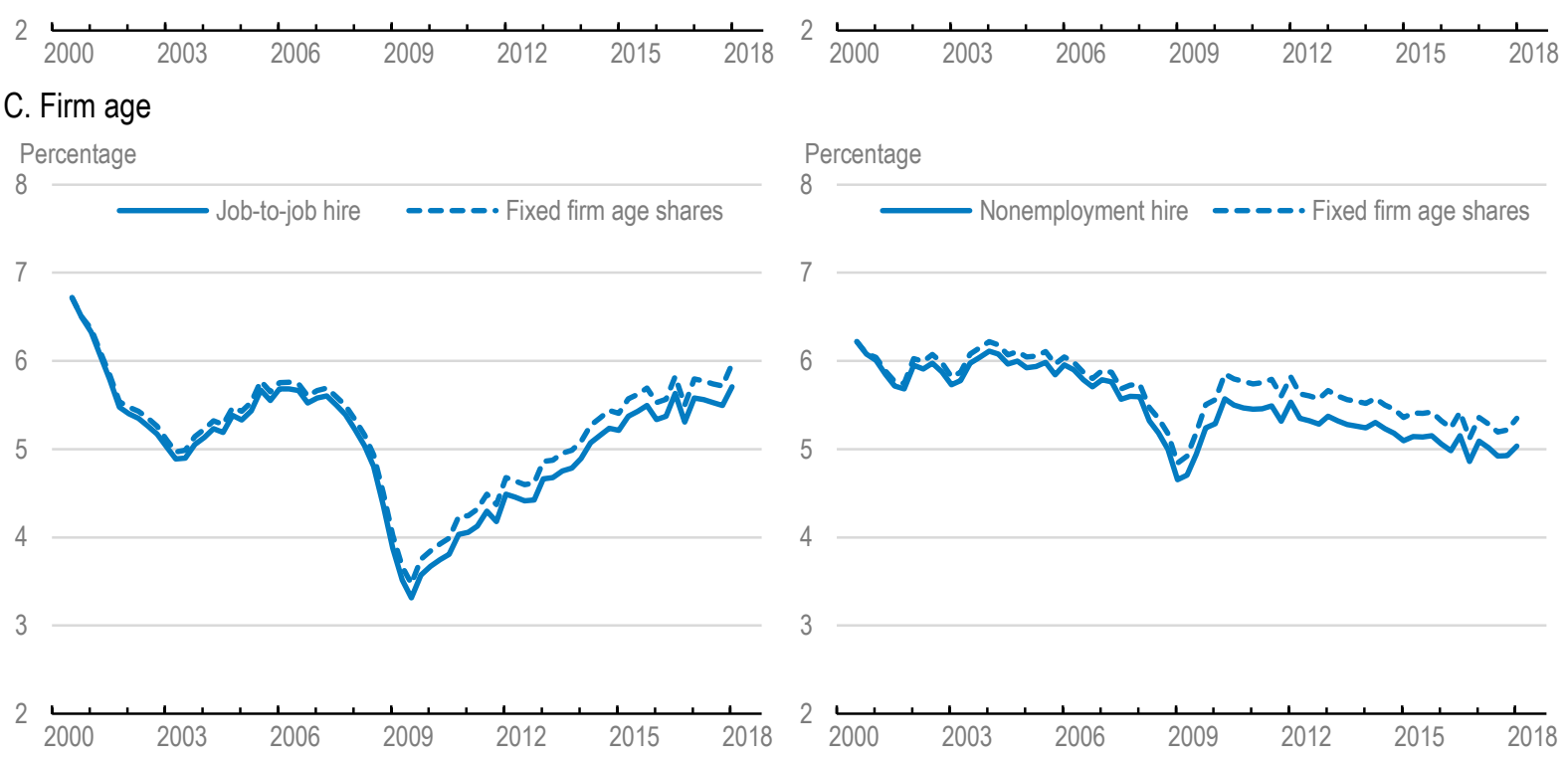

Note: Solid lines show the observed job-to-job and nonemployment hire and rates. Dashed lines show counterfactuals with compositional shares fixed at their 2000 levels (the calculation applies more groups than shown in Figure 21) and only accounting for within group changes. Source: OECD calculations based on Job-to-Job Flows database, Census Bureau. 


\section{Tables}

Table A.1. Employment and job-to-job distribution by sex

Percentage, average 2000 Q2-2018 Q1

\begin{tabular}{l|r|r|r}
\hline & Men & Women & Total \\
\hline Share of employment & 50.7 & 49.3 & 100 \\
\hline Share of job-to-job hire & 53.2 & 46.8 & 100 \\
\hline
\end{tabular}

Source: OECD calculations based on Job-to-Job Flows database, Census Bureau.

Table A.2. Employment and job-to-job distribution by education

Percentage, average 2000 Q2-2018 Q1

\begin{tabular}{l|c|c|c|c|c}
\hline & $\begin{array}{c}\text { Less than high } \\
\text { school }\end{array}$ & High school only & Some college & $\begin{array}{c}\text { Bachelor's degree or } \\
\text { advanced degree }\end{array}$ & Total \\
\hline Share of employment & 12.2 & 27.0 & 31.6 & 29.2 & 100 \\
\hline Share of job-to-job hire & 15.8 & 28.9 & 31.7 & 23.6 & 100 \\
\hline
\end{tabular}

Note: Workers aged 24 or younger are excluded.

Source: OECD calculations based on Job-to-Job Flows database, Census Bureau.

Table A.3. Employment and job-to-job distribution by race and ethnicity

Percentage, average 2000 Q2-2018 Q1

\begin{tabular}{|c|c|c|c|c|c|c|c|}
\hline & \multicolumn{5}{|c|}{ Race } & \multicolumn{2}{|c|}{ Ethnicity } \\
\hline & White & $\begin{array}{c}\text { Black or } \\
\text { African American }\end{array}$ & Asian & $\begin{array}{l}\text { American } \\
\text { Indian }\end{array}$ & Other & $\begin{array}{l}\text { Not Hispanic } \\
\text { or Latino }\end{array}$ & $\begin{array}{l}\text { Hispanic } \\
\text { or Latino }\end{array}$ \\
\hline Share of employment & 79.8 & 12.1 & 5.2 & 1.0 & 1.9 & 87.0 & 13.0 \\
\hline Share of job-to-job hire & 76.6 & 15.4 & 4.3 & 1.2 & 2.5 & 84.8 & 15.2 \\
\hline
\end{tabular}

Note: Other includes native Hawaiian or other pacific islander as well as two or more race groups.

Source: OECD calculations based on Job-to-Job Flows database, Census Bureau.

Table A.4. Job-to-job moves within and between States and industries by sex

Distribution of job-to-job moves by sex, 2010 Q2-2016 Q1

\begin{tabular}{rr|r|r|r}
\hline \multicolumn{1}{|l|}{ Male } & Within industries & Between industries & Total \\
\hline Within States & 30.0 & 51.9 & 82.0 \\
\hline Between States & 7.8 & 10.3 & 18.0 \\
\hline Total & 37.8 & 62.2 & 100.0 \\
\hline Female & Within industries & Between industries & Total \\
\hline & 33.4 & 52.2 & 85.6 \\
\hline Within States & 5.9 & 8.5 & 14.4 \\
\hline Between States & 39.3 & 60.7 & 100.0 \\
\hline Total & & & \\
\hline
\end{tabular}

Note: Industries are defined at the 2-digit NAICS level.

Source: OECD calculations based on Job-to-Job Flows database, Census Bureau. 
Table A.5. Job-to-job moves within and between States and industries by education

Distribution of job-to-job moves by education groups, 2010 Q2-2016 Q1

\begin{tabular}{rr|r|r|r}
\hline Less than high school & Within industries & Between industries & Total \\
\hline & Within States & 32.6 & 47.4 & 80.0 \\
\hline Between States & 7.2 & 12.8 & 20.0 \\
\hline Tigh school only & Total & 39.8 & 60.2 & 100 \\
\hline & Within States & Within industries & Between industries & Total \\
\hline Between States & 32.5 & 49.5 & 82.0 \\
\hline Total & 7.4 & 10.6 & 18.0 \\
\hline Some college & 39.9 & 60.1 & 100 \\
\hline & Within States & Within industries & Between industries & Total \\
\hline Between States & 33.2 & 48.8 & 82.0 \\
\hline Total & 7.6 & 10.4 & 18.0 \\
\hline Bachelor's or advanced degree & 40.8 & 59.2 & 100 \\
\hline Within States & Within industries & Between industries & Total \\
\hline Between States & 32.9 & 44.9 & 77.8 \\
\hline Total & 9.7 & 12.5 & 22.2 \\
\hline
\end{tabular}

Note: Industries are defined at the 2-digit NAICS level.

Source: OECD calculations based on Job-to-Job Flows database, Census Bureau.

Table A.6. Job-to-job moves within and between States and industries by race/ethnicity Distribution of job-to-job moves by race and ethnicity groups, 2010 Q2-2016 Q1

\begin{tabular}{rr|r|r|r}
\hline \multicolumn{1}{l|}{ White } & Within industries & Between industries & Total \\
\hline & Within States & 31.6 & 52.9 & 84.5 \\
\hline & Between States & 7.3 & 8.2 & 15.5 \\
\hline Black or African-American & Total & 38.9 & 61.1 & 100.0 \\
\hline & & Within industries & Between industries & Total \\
\hline & Wetween States & 32.1 & 54.3 & 86.3 \\
\hline Tsian & Total & 5.9 & 7.7 & 13.7 \\
\hline & & 38.0 & 62.0 & 100.0 \\
\hline Within States & Within industries & Between industries & Total \\
\hline Between States & 33.2 & 45.2 & 78.4 \\
\hline Hispanic or Latino & Total & 10.5 & 11.1 & 21.6 \\
\hline & 43.7 & 56.3 & 100.0 \\
\hline & Within States & Within industries & Between industries & Total \\
\hline Between States & 33.0 & 53.7 & 86.7 \\
\hline Total & 5.4 & 7.9 & 13.3 \\
\hline
\end{tabular}

Note: Industries are defined at the 2-digit NAICS level.

Source: OECD calculations based on Job-to-Job Flows database, Census Bureau. 
Table A.7. All education groups have positive earnings returns from interstate job-to-job moves

Average earnings regressions by education groups, 2000 Q4-2018 Q1

\begin{tabular}{|c|c|c|c|c|c|c|c|c|}
\hline $\begin{array}{l}\text { Dependent variable: } \\
\text { Change in log earnings from job-to-job } \\
\text { move }\end{array}$ & $\begin{array}{l}\text { Less than } \\
\text { high school }\end{array}$ & & $\begin{array}{l}\text { High school } \\
\text { only }\end{array}$ & & $\begin{array}{l}\text { Some } \\
\text { college }\end{array}$ & & $\begin{array}{l}\text { Bachelor's or } \\
\text { advanced } \\
\text { degree }\end{array}$ & \\
\hline \multicolumn{9}{|l|}{ Job-to-job move to: } \\
\hline Neighbouring State, within industry & 0.01 & *** & 0.02 & 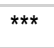 & 0.02 & *** & 0.04 & *** \\
\hline Non-neighbouring State, within industry & 0.03 & *** & 0.03 & *** & 0.04 & $\star * \star *$ & 0.07 & *** \\
\hline Within State, between industries & 0.01 & $* * *$ & 0.01 & $* * *$ & 0.01 & $\star * *$ & 0.00 & \\
\hline Neighbouring State, between industries & 0.04 & *** & 0.04 & *** & 0.04 & *** & 0.05 & *** \\
\hline Non-neighbouring State, between industries & 0.03 & *** & 0.03 & $\star \star \star *$ & 0.04 & $\star \star \star *$ & 0.07 & *** \\
\hline Distance between origin and destination States & -0.01 & $* * *$ & -0.01 & 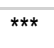 & 0.00 & $\star * *$ & 0.01 & *** \\
\hline Distance squared & 0.00 & $\star * \star$ & 0.00 & & 0.00 & & 0.00 & $* * *$ \\
\hline \multicolumn{9}{|l|}{ Unemployment rates } \\
\hline Destination State, quarter $t$ & -0.01 & $\star \star \star *$ & -0.01 & $\star \star \star *$ & -0.01 & *** & 0.00 & \\
\hline Destination State, quarter t-1 & 0.00 & & 0.00 & *** & 0.00 & *** & 0.00 & \\
\hline Origin State, quarter $\mathrm{t}$ & -0.01 & $* * *$ & -0.01 & *** & -0.01 & $\star * *$ & 0.00 & \\
\hline Origin State, quarter $\mathrm{t}-1$ & 0.03 & $\star * \star$ & 0.02 & *** & 0.02 & *** & 0.01 & *** \\
\hline Female & 0.00 & * & 0.00 & $\star \star \star *$ & 0.00 & & 0.01 & *** \\
\hline Constant & 0.02 & *** & 0.00 & & -0.01 & & -0.03 & $* * *$ \\
\hline \multicolumn{9}{|l|}{ Fixed effects } \\
\hline Destination State & $x$ & & $x$ & & $x$ & & $x$ & \\
\hline Origin State & $x$ & & $x$ & & $x$ & & $x$ & \\
\hline Destination industry & $x$ & & $x$ & & $x$ & & $x$ & \\
\hline Origin industry & $x$ & & $x$ & & $x$ & & $x$ & \\
\hline Year-quarter & $x$ & & $x$ & & $x$ & & $x$ & \\
\hline Observations & $4,796,265$ & & $6,516,113$ & & $7,048,308$ & & $6,634,467$ & \\
\hline Variables & 219 & & 219 & & 219 & & 219 & \\
\hline Clusters & 457,108 & & 534,986 & & 553,839 & & 535,574 & \\
\hline $\mathrm{R}^{2}$ & 0.11 & & 0.14 & & 0.13 & & 0.10 & \\
\hline
\end{tabular}

Note: Earnings gain estimated relative to job-to-job move within State and within industry (excluded category). All job-to-job moves (with and without brief nonemployment are included). Log difference between average earnings before (t-1) and after ( $t+1$ or $t+2)$ job move. Earnings are deflated by the PCE deflator. Monthly State unemployment rates are sourced from BLS and averaged by quarter.

Source: OECD calculations based on Job-to-Job Flows database, Census Bureau. 